SABRINA MARQUES MOGENTALE

Efeitos da flavomicina ou da monensina sobre a fermentação e a digestão ruminal e total em bovinos 


\section{Efeitos da flavomicina ou da monensina sobre a fermentação e a digestão ruminal e total em bovinos}

Dissertação apresentada ao Programa de Pósgraduação em Nutrição Animal da Faculdade de Medicina Veterinária e Zootecnia da Universidade de São Paulo para obtenção do título de Mestre em Medicina Veterinária

\section{Departamento:}

Nutrição e Produção Animal

Área de concentração:

Nutrição Animal

\section{Orientador:}

Prof. Dr. Paulo Henrique Mazza Rodrigues 
Autorizo a reprodução parcial ou total desta obra. para fins acadêmicos. desde que citada a fonte.

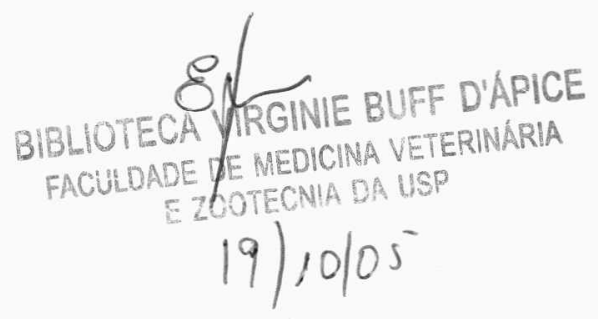

DADOS INTERNACIONAIS DE CATALOGAÇÃO-NA-PUBLICAÇÃO

(Biblioteca da Faculdade de Medicina Veterinária e Zootecnia da Universidade de São Paulo)

\section{T.1567 Mogentale, Sabrina Marques}

FMVZ Efeitos da flavomicina ou da monensina sobre a fermentaçào e a digestão ruminal e total em bovinos / Sabrina Marques Mogentale. - Pirassununga : S. M. Mogentale, 2005.

$105 \mathrm{f}$ : : il.

Dissertação (mestrado) - Universidade de São Paulo. Faculdade de Medicina Veterinária e Zootecnia. Departamento de Nutrição e Produção Animal, 2005.

Programa de Pós-graduação: Nutrição Animal.

Área de concentração: Nutrição Animal.

Orientador: Prof. Dr. Paulo Henrique Mazza Rodrigues.

1. Ionóforo. 2. Antibiótico não-ionóforo. 3. Ácidos graxos voláteis. 4. Digestibilidade. 5. Degradabilidade. 6. Ruminantes. I. Título. 


\section{UNIVERSIDADE DE SÃO PAULO \\ Faculdade de Medicina Veterinaria e Zootecnia \\ Assistência Acadêmica}

Comissão de Bioética

\section{CERTIFICADO}

Certificamos que o Projeto intitulado "Efeitos da enramicina e da monensina sódica sobre a fermentação ruminal e digestão total em bovinos", protocolo $n^{\circ} 706 / 2005$, não utilizando 12 bovinos, sob a responsabilidade do Prof. Dr. Paulo Henrique Mazza Rodrigues, está de acordo com os princípios éticos de experimentação animal da Comissão de Bioética da Faculdade de Medicina Veterinária e Zootecnia da Universidade de São Paulo e foi aprovado "ad referendun".

(We certify that the Research "Effects of enramycin and monensin on ruminal fermentation and total digestibility in bovine", protocol number 706/2005, utilizing 12 bovines, under the responsibility of Prof. Dr. Paulo Henrique Mazza Rodrigues, agree with Ethical Principles in Animal Research adopted by Bioethic Commission of the Faculty of Veterinary Medicine and Zootechny of University of São Paulo and was approved "ad referendun", meeting).

São Paulo, 05 de outubro de 2005

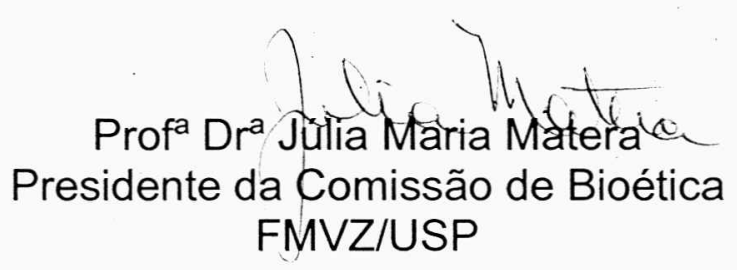




\section{FOLHA DE AVALIAÇÃO}

Nome: MOGENTALE, Sabrina Marques

Título: Efeitos da flavomicina ou da monensina sobre a fermentação e a digestão ruminal e total em bovinos

Dissertação apresentada ao Programa de Pósgraduação em Nutrição Animal da Faculdade de Medicina Veterinária e Zootecnia da Universidade de São Paulo para obtenção do título de Mestre em Medicina Veterinária

Aprovado em:

Banca Examinadora

Prof. Dr.

Assinatura :

Prof. Dr.

Assinatura :

Prof. Dr.

Assinatura :
Instituição:

Julgamento:

Instituição:

Julgamento:

Instituição:

Julgamento: 
À minha querida e amada mãe, Maria Antônia, e ao meu querido e amado pai, Freddy, por acreditarem em mim, mesmo quando tudo parecia errado... eles estavam lá torcendo e dando todo o apoio necessário para o meu crescimento,

Ao meu irmão Ricardo, que sempre me deu a maior força em todos os sonhos que desejei realizar,

Ao meu avô Alcino e à minha avó Maria Luiza, dois seres de muita luz em minha vida,

Ao meu avô Agenor, à minha avó Geny, dois anjos terrenos,

À minha família americana, Harry, Diana e Nichole, por, mesmo de longe, me mandarem esta energia para que tudo desse certo no final,

Dedico este trabalho, com todo o meu amor, respeito e gratidão!

"A vida é uma peça de teatro que não permite ensaios...

Por isso, cante, ria, dance, chore e viva intensamente

cada momento da sua vida...

Antes que a cortina se feche,

e a peça termine sem aplausos."

(Charles Chaplin) 
Ao Professor Doutor Paulo Henrique Mazza Rodrigues, pela confiança depositada em mim e por ser meu orientador nos momentos mais necessários deste mestrado,

Ao Professor Doutor Felix Ribeiro de Lima, orientador de coração, por ajudar-me em todos os momentos vividos neste departamento em busca de uma verdade,

À Doutora Laura Borgatti, por tudo o que me ensinou e pela sincera amizade,

Às companheiras de mestrado Cris Cortelazzi e Polyana Arruda pelo apoio e momentos de descontração nestes anos,

Registro aqui meus mais sinceros agradecimentos! 


\section{AGRADECIMENTOS}

À todos os docentes do Departamento de Nutrição e Produção Animal (VNP),

Ao CNPq e à Pró-Reitoria de Pós-graduação da USP, pela concessão da bolsa de estudos,

A todos os funcionários do VNP e em especial à Cris, Alessandra, Lúcia e Zequinha, que tanto nos ajudaram pelo empenho e eficiência e pela delicadeza com que nos distinguiram,

A dois incríveis profisssionais, Gilmar e Everson, da seção do estábulo experimental, pelo cuidados com os animais e pela atenção, respeito e amizade com que sempre nos trataram,

À equipe do laboratório de bromatologia do VNP: Ari, pelos ensinamentos, pela paciência e dedicação dispensados à mim e ao presente trabalho, Gilson, Simi e Isabel, pela inestimável ajuda nas análise laboratoriais,

Ao Professor Mário Binelli, por me introduzir ao mundo da pesquisa e à USP e pela sincera amizade,

À Professora Doutora Kiki, pela amizade e por todos os momentos de incentivo ao saber,

À Ms. Raquel Fernandes, companheira de alojamento, de departamento e de balada, sempre me dando as maiores broncas.

Ao pessoal da fábrica de ração do Campus Administrativo de Pirassununga,

A todos meus colegas da pós-graduação da FMVZ, pela amizade e convivência harmônica e feliz,

À Vanessa, Alemão, Ana Paula (Borrega), Eliza (Ticket), Assuka (Gozada), Nayara (Peidinho), Elizabeth (Friera), Letícia (Eva), Daniele (Choco), amizades especiais semeadas durante estes três anos e que espero que rendam frutos para toda a vida,

Aos todos meus amigos que, apesar da distância, sempre estiveram perto e torceram por mim, em especial à Juliana, Joana, Simone, Roberta, Telina, Carlinha, Celso, Monika, Maria Marcondes. Obrigada pelo que foram, são e sempre serão para mim!

A todos os novos amigos que conheci em Pirassununga, Lucas, Thiago, Luís e Marta, Neto, Matheus, Matheus Fonseca, Marcelo (do Biela), Igor, João, Lopes, Lucas Faria, Fábio, Chicão, Dú Cabelo, Paulinho Branco, Cris Naga, todos unidos pela mais linda arte, a música.

A todos os funcionários do Campus (bandejão, secretaria, administração, limpeza, marcenaria, serralheria) pela amizade sincera neste tempo em Pirassununga, nunca os vou esquecer!

A todos os que contribuíram direta ou indiretamente para realização deste trabalho, 


\section{LISTA DE TABELAS}

\section{CAPÍTULO III}

Tabela 1 - Proporções de ingredientes utilizados e composição bromatológica das rações, com base na matéria seca.

Tabela 2 - Consumo de matéria seca obtido com os tratamentos .................. $\quad 59$

Tabela 3 - $\quad$ Padrão de fermentação ruminal obtido com os tratamentos ......... $\quad 61$

\section{CAPÍTULO IV}

Tabela 1 - Proporções de ingredientes utilizados e composição bromatológica das rações, com base na matéria seca

Tabela 2 - Composição bromatológica dos alimentos

Tabela 3 - Degradabilidade ruminal da FDN da cana-de-açúcar obtida com os tratamentos

Tabela 4 - Degradabilidade ruminal do amido dos grãos de milho obtida com os tratamentos

Tabela 5 - Degradabilidade ruminal da proteína bruta do farelo de soja obtida com os tratamentos

Tabela 6 - Consumo de matéria seca digestível e de NDT obtido com os tratamentos

Tabela 7 - $\quad$ Digestibilidade aparente da MS da dieta e suas frações obtidas com os tratamentos 


\section{LISTA DE FIGURAS}

\section{CAPÍTULO III}

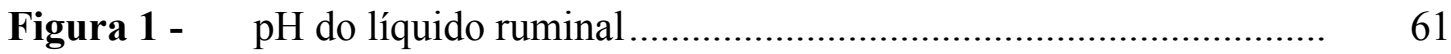

Figura 2 - Concentração total de AGVs (mM) no líquido ruminal ............... 62

Figura 3 - $\quad$ Proporção molar de ácido acético no líquido ruminal .................. $\quad 64$

Figura 4 - $\quad$ Proporção molar de ácido propiônico no líquido ruminal ............ $\quad 65$

Figura 5 - Relação acético/propiônico no líquido ruminal ............................. 67

Figura 6 - Concentração de nitrogênio amoniacal $(\mathrm{mg} / \mathrm{dL})$ no líquido ruminal 


\begin{tabular}{|c|c|c|c|}
\hline AGVs & - ácidos graxos voláteis & $V F A s$ & - volatile fatty acids \\
\hline CMS & - consumo de matéria seca & $D M I$ & - dry matter intake \\
\hline $\mathrm{EB}$ & - energia bruta & $G E$ & - gross energy \\
\hline $\mathrm{EE}$ & - extrato etéreo & $E E$ & - ether extract \\
\hline EÑN & - extrativo não nitrogenado & $N F E$ & - nitrogen-free extract \\
\hline FB & - fibra bruta & $C F$ & - crude fiber \\
\hline FDA & - fibra em detergente ácido & $A D F$ & - acid detergent fiber \\
\hline FDN & - fibra em detergente neutro & $N D F$ & - neutral detergent fiber \\
\hline $\mathrm{h}$ & - hora & $h$ & - hour \\
\hline $\mathrm{kg}$ & - quilos & $k g$ & - kilos \\
\hline $\mathrm{MO}$ & - matéria orgânica & $O M$ & - organic matter \\
\hline MS & - matéria seca & $D M$ & - dry matter \\
\hline $\mathrm{N}$ & - nitrogênio & $N$ & - nitrogen \\
\hline NDT & - nutrientes digestíveis totais & $T D N$ & - total digestible nutrients \\
\hline $\mathrm{N}-\mathrm{NH}_{3}$ & - nitrogênio amoniacal & $\mathrm{N}-\mathrm{NH}_{3}$ & - ammoniacal-N \\
\hline NS & - não significativo & $N S$ & - non significant \\
\hline $\mathrm{P}$ & - fósforo & $P$ & - phosphorus \\
\hline PB & - proteína bruta & $C P$ & - crude protein \\
\hline Prob. & - probabilidade & Prob. & - probability \\
\hline PV & - peso vivo & $B W$ & - body weight \\
\hline Trat. & - tratamento & Treat. & - treatment \\
\hline
\end{tabular}




\section{RESUMO}

MOGENTALE, S. M. Efeitos da flavomicina ou da monensina sobre a fermentação e a digestão ruminal e total em bovinos. [Effects of flavomycin or monensin on ruminal fermentation and ruminal and total digestion in bovine]. 2005. 105 f. Dissertação (Mestrado em Medicina Veterinária) - Faculdade de Medicina Veterinária e Zootecnia, Universidade de São Paulo, Pirassununga, 2005.

Foram estudados os efeitos da flavomicina ou da monensina sobre a fermentação e digestão ruminal e total em bovinos. Doze fêmeas bovinas não gestantes e não lactantes, portadoras de fístula ruminal, pesando em média $736 \mathrm{~kg}$, foram distribuídas inteiramente ao acaso em três grupos experimentais: controle (ausência de antibiótico), tratado com flavomicina (antibiótico não-ionóforo) e outro tratado com monensina (antibiótico ionóforo). Foram administradas doses de $20 \mathrm{mg}$ e $300 \mathrm{mg} / \mathrm{animal} / \mathrm{dia}$, de flavomicina e monensina, respectivamente. Utilizouse um período experimental de 21 dias, sendo os 16 primeiros destinados à adaptação dos animais à dieta, composta de $60 \%$ de concentrado (milho, farelo de soja e mistura mineral) e 40\% de volumoso (basicamente de cana-de-açúcar). O $21^{\circ}$ dia foi utilizado para avaliação do consumo de MS e colheitas de líquido ruminal, realizadas às $0 ; 2 ; 4 ; 6 ; 8 ; 10$ e 12 horas após a primeira refeição. Os 10 últimos dias foram destinados à aplicação do marcador $(15 \mathrm{~g}$ de óxido crômico/animal/dia), e os 5 últimos, destinados à avaliação do consumo de MS, colheita de fezes, amostragem dos alimentos e também à avaliação da digestão ruminal (degradabilidade in situ), pela técnica dos sacos de nylon, incubando-se cana-de-açúcar, milho em grãos ou farelo de soja. A monensina diminuiu a proporção molar de ácido acético e aumentou a de propiônico $(27,2 \%)$, em relação ao grupo controle, e aumentou a degradabilidade efetiva ruminal do amido dos grãos de milho, em relação à flavomicina. A flavomicina diminuiu a taxa de degradação da PB do farelo de soja, em relação ao controle e monensina. Nenhum dos antibióticos testados alterou a concentração total dos AGVs, ácido butírico, $\mathrm{pH}$, concentração 
ruminal de $\mathrm{N}-\mathrm{NH}_{3}$ ou consumo de $\mathrm{MS}$. Tão pouco foram alteradas a degradabilidade efetiva da FDN da cana-de-açúcar, CMS digestível, digestibilidade da MS, PB, EE, EÑN, FB, FDA, FDN, EB, amido ou o NDT da dieta.

Palavras-chave: Ionóforo. Antibiótico não-ionóforo. Ácidos graxos voláteis. Digestibilidade.

Degradabilidade. Ruminantes. 


\begin{abstract}
MOGENTALE, S. M. Effects of flavomycin or monensin on ruminal fermentation and ruminal and total digestion in bovine [Efeitos da flavomicina ou da monensina sobre a fermentação e a digestão ruminal e total em bovinos]. 2005. 105 f. Dissertação (Mestrado em Medicina Veterinária) - Faculdade de Medicina Veterinária e Zootecnia, Universidade de São Paulo, Pirassununga, 2005.
\end{abstract}

The effects of flavomycin or monensin on ruminal fermentation and ruminal and total digestion in bovines were investigated. Twelve non-pregnant and non-lactating rumenfistulated cows (736 kg of BW) were randomly assigned to three treatment groups: control (no antibiotic), flavomycin-treated (non-ionophore antibiotic) and monensin-treated (ionophore antibiotic). Treatment doses were 20 and 300mg/animal/day of flavomycin and monensin, respectively. Twenty-one day subperiod was used, the first sixteen for diet adaptation. Diet was composed by $60 \%$ concentrate (corn, soybean meal and mineral mixture) and $40 \%$ roughage (basically sugar cane). The $21^{\text {st }}$ day was used for the evaluation of DMI and for ruminal fluid sampling at $0,2,4,6,8,10$ and 12 hours after the first meal. The last 10 days were used for external marker administration ( $15 \mathrm{~g}$ of chromic oxide/ animal/day), and the last 5 days, for DMI evaluation, feces collection, feed sampling and evaluation of ruminal degradability using the nylon bag technique. Bags containing corn grain, soybean meal or sugar cane were incubated through the rumen fistula from the $17^{\text {th }}$ up to the $21^{\text {st }}$ day. Monensin decreased the molar proportion of acetic acid and increased the propionic acid in $27.2 \%$, compared to control group and increased the effective degradability of corn grain starch, compared to flavomycin. Flavomycin decreased the degradation rate of soybean meal crude protein compared to control and monensin groups. Total VFA concentrations, molar proportion of butyric acid, $\mathrm{pH}$, ammoniacal-N concentration or DMI were not influenced by the addition of either antibiotics; neither were the effective degradability of sugar cane NDF, 
digestible DMI or DM, CP, EE, NFE, CF, ADF, NDF, GE and starch digestibility nor the TDN of the diet.

Key words: Ionophore. Non-Ionophore antibiotic. Volatile fatty acids. Digestibility. Degradability. Ruminants. 


\section{SUMÁRIO}

\section{CAPÍTULO I}

1 INTRODUÇÃO

\section{CAPÍTULO II}

1 REVISÃO DE LITERATURA

1.1 MODO DE AÇÃO BÁSICO DOS ANTIBIÓTICOS.

1.1.1 Ionóforos.

1.2 MODO DE AÇÃO SISTÊMICO DOS ANTIBIÓTICOS IONÓFOROS E NÃO-IONÓFOROS.

1.2.2 Consumo de alimentos ........................................................... 28

1.2.3 Produção de metano ….................................................................. 30 
1.2.5 Utilização da proteína ….......................................................... 36

1.2.6 Volume ruminal e taxa de passagem......................................... 40

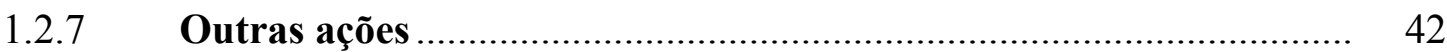

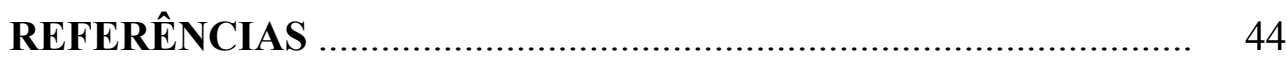

CAPÍTULO III - EFEITOS DA FLAVOMICINA OU DA MONENSINA SOBRE A FERMENTAÇÃO RUMINAL EM BOVINOS

1

INTRODUÇÃO

2 MATERIAL E MÉTODOS 54 
CAPÍTULO IV - EFEITOS DA FLAVOMICINA OU DA MONENSINA SOBRE A DIGESTÃo RUMINAL E TOTAL EM BOVINOS

1

INTRODUÇÃO 78

2 MATERIAL E MÉTODOS 80 


\section{CAPÍTULO I}

\section{INTRODUÇÃO}

$\mathrm{Na}$ nutrição de ruminantes, durante muito tempo procurou-se manipular a fermentação ruminal, melhorando sua eficiência, seja através do aumento da produção do ácido propiônico, da diminuição da metanogênese ou da diminuição da proteólise e deaminação de proteínas no rúmen. Inicialmente este objetivo foi perseguido apenas através da manipulação da dieta. Entretanto, a descoberta de compostos químicos ativos no rúmen abriu grandes perspectivas nessa área das ciências agrícolas (BERGEN; BATES, 1984).

Uma classe desses compostos que vem obtendo considerável sucesso como aditivos alimentares são os chamados antibióticos ionóforos polieter carboxílicos, os quais são substâncias produzidas por várias cepas de Streptomyces sp, e, em menor escala, alguns antibióticos não-ionóforos (MAROUNEK; DUŠKOVÁ; SKŘIVANOVÁ, 1998). Na classe dos ionóforos, podemos citar a monensina, lasalocida, salinomicina, narasina e outras. Por definição, ionóforos são moléculas de baixo peso molecular capazes de interagir estequiometricamente com íons metálicos, servindo como transportadores mediante os quais estes íons podem ser levados através de uma membrana lipídica bimolecular (OVCHINNIKOV, 1979). 
Já os não-ionóforos, como a avoparcina, flavomicina, tilosina, bacitracina, virginamicina, promovem o crescimento do animal, inicialmente através da modificação da característica fermentativa do rúmen (VAN DER MERWE; DUGMORE; WALSH, 2001).

As respostas alcançadas com a utilização dos ionóforos são bastantes variáveis, fenômeno que pode ser explicado, em parte, pelas diferentes condições experimentais (GALLOWAY et al., 1993).

O presente trabalho objetivou estudar os efeitos da aplicação da monensina ou flavomicina sobre: consumo de alimentos; alguns parâmetros da fermentação ruminal, tais como pH ruminal, produção de ácidos graxos voláteis e concentrações ruminais de nitrogênio amoniacal; digestibilidade ruminal in situ da proteína bruta, amido e fibra de alimentos concentrados ou volumosos, bem como sobre a digestibilidade in vivo da matéria seca e nutrientes da dieta, considerando dietas predominantemente concentradas, tendo a cana-de-açúcar como único volumoso. 


\section{CAPÍTULO II}

\section{REVISÃO DE LITERATURA}

Conforme proposto por Schelling (1984), pode-se diferenciar os modos de ação dos antibióticos, em dois tipos: um básico, ocorrendo na membrana celular dos microorganismos ruminais, e outro sistêmico, composto por sete categorias de ação, resultantes da alteração do metabolismo das bactérias do rúmen e afetando a resposta animal. Desta forma, tais antibióticos possuem a capacidade de aumentar a eficiência do metabolismo energético e protéico no rúmen e no animal, além de diminuírem a incidência de distúrbios digestivos (BERGEN; BATES, 1984).

\subsection{MODO DE AÇÃO BÁSICO DOS ANTIBIÓTICOS}

\subsubsection{Ionóforos}

O modo básico de ação dos ionóforos parece resultar de interferência no fluxo iônico normal através da membrana dos microorganismos e dissipação do gradiente de prótons e cátions, sistemas estes responsáveis pelo aporte de aminoácidos, 
açúcares e outros íons contra um gradiente de concentração (BERGEN; BATES, 1984). Como esta interferência pode ser compensada as custas de ATP, as células que possuem um sistema de transporte de elétrons acoplado à extrusão de prótons e/ou síntese de ATP terão melhores condições de sobreviver, apesar das maiores exigências em energia, em detrimento das células que dependem da fosforilação em nível de substrato, via ATPase (BERGEN; BATES, 1984).

A membrana celular é responsável por regular o balanço químico entre o meio interno e externo da célula, sendo este equilíbrio mantido por um mecanismo chamado de bomba iônica. O ionóforo, ao ligar-se ao cátion de maior afinidade, transporta-o através da membrana celular para dentro da bactéria, e esta, por mecanismo da bomba iônica, na tentativa de manter este equilíbrio, utiliza sua energia de forma excessiva até deprimir as suas reservas. Como conseqüência disto, a bomba iônica não opera eficientemente, provocando um desequilíbrio, devido a uma maior concentração iônica (cátions, prótons) dentro da célula do que fora. Ocorre, então, aumento da pressão osmótica, resultando na entrada de água em excesso e, com isso, a célula entumece, tendendo a romper-se (BARRAGRY, 1994). O resultado disto é uma mudança no ecossistema microbiano, favorecendo alguns microorganismos, principalmente as bactérias Gram negativas, produtoras de ácido propiônico e mais resistentes e inibindo Gram positivas, que são as maiores produtoras de ácidos acético, butírico e láctico, $\mathrm{H}_{2}$ e metano (MCCAUGHEY; WITTENBERG; CORRIGAN, 1997). 
Estes antibióticos formam complexos com cátions mono e divalentes, como $\mathrm{K}^{+}, \mathrm{Na}^{+}, \mathrm{Ca}^{++}$e $\mathrm{Mg}^{++}$, apesar de não terem a mesma afinidade para todos estes íons. Por exemplo, a monensina medeia principalmente $\mathrm{o} \mathrm{Na}^{+}$, pois sua afinidade à este íon é dez vezes maior do que ao $\mathrm{K}^{+}$, e não tem afinidade a íons bivalentes; entretanto, a lasalocida tem maior afinidade para $\mathrm{o} \mathrm{K}^{+}$e menor atração ao $\mathrm{Ca}^{++}$e $\mathrm{Na}^{+}$ (PRESSMAN, 1976).

Conforme relatos de Schelling (1984), a atividade específica das reações de troca iônica no nível celular, catalisadas pelos diferentes ionóforos utilizados hoje em ruminantes, depende da afinidade do cátion com o ionóforo, do $\mathrm{pH}$, do gradiente de concentração relativo do íon e do mecanismo específico pelo qual ocorre o deslocamento deste.

\subsubsection{Não-Ionóforos}

São poucas as informações disponíveis sobre o efeito de promoção de crescimento destes antibióticos, particularmente em ruminantes. Seu modo de ação sobre a população bacteriana do rúmen parece diferir dos já bem caracterizados ionóforos (FÉBEL et al., 1988). A flavomicina é um antibiótico fosfoglicolipídico que atua inibindo o crescimento bacteriano, através da inibição competitiva da enzima que cataliza a reação de transglicosilação durante a síntese da camada peptideoglicana (VAN HEIJENOORT, 2001). Esta inibição ocorre principalmente em bactérias Gram positivas, as quais possuem maior camada peptideoglicana. Porém, podem inibir 
bactérias Gram negativas que possuem característica de Gram positiva ou se comportam similarmente.

Mas, principalmente, a flavomicina inibe dois grupos de bactérias, as da espécie AAPA (alta atividade de produção de amônia) e as fusobactérias Gram negativas (EDWARDS et al., 2005). Alguns outros estudos mostram que as bactérias da espécie Fusobacterium possuem alta taxa de deaminação e também deveriam ser consideradas da espécie AAPA, quais são bactérias que causam conversão excessiva de aminoácidos dietários em amônia, pois possuem alta atividade específica de deaminação (RUSSELL; ONODERA; HINO, 1991).

\subsection{MODO DE AÇÃO SISTÊMICO DOS ANTIBIÓTICOS IONÓFOROS E NÃO-IONÓFOROS}

Quanto ao tipo sistêmico, o modo de ação dos antibióticos ionóforos é constituído por sete formas resultantes do tipo básico (SCHELLING, 1984) e listados da seguinte maneira: modificação na produção de ácidos graxos voláteis; modificação no consumo de alimentos; modificação na produção de gases; modificações nas digestibilidades; modificação na utilização da proteína; modificações no enchimento e taxa eferente de passagem ruminais e outros. Por não se encontrar referência semelhante para os antibióticos não-ionóforos, adotou-se a mesma classificação para estes antibióticos. 


\subsubsection{Produção de AGVs}

Classicamente os ionóforos são conhecidos por alterarem a proporção molar de ácidos graxos voláteis (AGVs) produzidos no rúmen, devido ao aumento do ácido propiônico $\left(\mathrm{C}_{3}\right)$ em detrimento dos ácidos acético $\left(\mathrm{C}_{2}\right)$ e/ou butírico $\left(\mathrm{C}_{4}\right)$, geralmente sem causar grandes alterações sobre a produção total de AGVs.

Vários fatores podem alterar os efeitos dos ionóforos sobre os AGVs, tais como: nível de fibra, energia, proteína, período de adaptação, momento da colheita, espécie animal, tipo de ionóforo utilizado e outros.

A diferença na proporção volumoso:concentrados, ou no teor de fibra na dieta, parece alterar a magnitude da resposta encontrada na proporção molar de AGVs ocasionada pelos ionóforos, apesar dos resultados serem controversos. Thornton e Owens (1981) observaram que a monensina aumentou a proporção molar de propionato em $65,6 \%$ em uma dieta com altos níveis de fibra (40\% de FDA) e somente $38,6 \%$ quando a mesma possuía baixos níveis (12\% de FDA). A diminuição na proporção molar de acetato foi semelhante entre as duas $(11,7 \%$ a $10,8 \%$, respectivamente) e não foram observadas alterações na concentração total de AGVs e proporção molar de butirato em qualquer das dietas.

Em um estudo in vitro, onde testou-se o efeito da monensina em dietas com $0 \%, 50 \%$ e $90 \%$ de concentrados, observou-se que a monensina aumentou a concentração de propionato em $17,1 \%$ e $47,9 \%$ para as dietas contendo $0 \%$ e $50 \%$ de concentrados, respectivamente, mas não alterou significativamente esta variável 
quando o meio continha 90\% de concentrados (GARCIA-LOPEZ; KUNG; ODOM, 1996). Esses últimos autores reconheceram a dose baixa utilizada como a causa da falta de efeito na dieta predominantemente concentrada.

Dados contrários foram obtidos em outro estudo in vitro, onde foram utilizados inóculos de animais alimentados com dieta rica em grãos ou em volumosos (RICHARDSON et al., 1976). Neste experimento, quando utilizou-se inóculo de animais alimentados com dieta predominantemente concentrada, diferentes concentrações de monensina diminuíram a produção de acetato, butirato, valerato e isovalerato e aumentaram a de propionato. Ao utilizar inóculo de animais submetidos à dieta predominantemente volumosa, esses efeitos foram observados somente com as concentrações mais elevadas do produto.

Em estudo in vivo, Ramanzin et al. (1997) observaram maiores efeitos da monensina sobre a proporção molar de propionato em vacas leiteiras submetidas a dietas com $50 \%$ de concentrados (aumento de $26,7 \%$ ) do que quando estas recebiam dietas com apenas $30 \%$ de concentrados (aumento de 8,9\%). Mesmo em novilhos, Zinn; Plascencia e Barajas (1994) observaram efeitos positivos da monensina em aumentar a proporção molar de propionato somente nas dietas com apenas $10 \%$ de volumosos (aumento de 9,4\%), mas observaram diminuição deste parâmetro quando a dieta possuía $20 \%$ de volumosos (diminuição de 5,5\%).

Experimentos realizados in vivo não observaram efeitos dos ionóforos sobre a concentração total ou sobre a proporção molar de AGVs dosados no líquido ruminal. Baile et al. (1979) não observaram qualquer efeito significativo da monensina sobre 
a proporção molar de AGVs, seja em novilhos submetidos a dietas predominantemente volumosa $(92 \%$ de volumoso $)$ ou concentrada $(85 \%$ de concentrados), bem como Fredrickson et al. (1993) ao administrarem bolus de liberação lenta de monensina a novilhos em regime de pastejo, Green et al. (1999) ao utilizarem o mesmo dispositivo em vacas leiteiras primíparas e multíparas recémparidas. Já Van Maanen et al. (1978) observaram aumento nas taxas de propionato de 49 e $76 \%$, utilizando a monensina em bezerros alimentados com dieta volumosa e concentrada, respectivamente.

A freqüente falta de resposta na alteração da proporção molar dos AGVs difere a flavomicina dos demais ionóforos, incluindo monensina, salinomicina, narasina e tetronasina, os quais promovem aumento na formação de propionato (NAGARAJA et al., 1997). Portanto, deve se esperar que a flavomicina apresente, em termos de atividade antimicrobiana, um modo de ação diferente comparado aos outros ionóforos.

Edwards et al. (2005) relataram que, em experimento com carneiros que receberam dieta mista de volumoso/concentrado, com inclusão de $20 \mathrm{mg}$ de flavomicina/dia, a proporção molar dos diferentes AGVs não foi alterada, bem como a proporção acetato:propionato, embora tenha ocorrido diminuição significativa na concentração total de AGVs. Este achado concorda parcialmente com experimento realizado por Alert, Poppe e Lohner (1993), onde, adicionando 50mg/animal/dia de flavomicina em touros holandeses, observaram que a flavomicina não alterou a 
proporção acetato:propionato, porém foi observada leve tendência no aumento da concentração total dos AGVs no rúmen.

No entanto, Murray, Rowe e Aitchison (1990), ao realizarem experimento com ovinos utilizando dois tipos de ração peletizada, uma baseada em alfafa debulhada e grão de tremoço, e outra baseada em trigo debulhado e farinha de peixe, relataram que a inclusão de flavomicina em ambas as dietas aumentou significativamente a proporção molar de propionato no fluido ruminal. Em outro experimento realizado com ovinos, adicionando metionina e flavomicina à dieta a base de tremoço, Murray, Rowe e Speijers (1991) observaram que a concentração total de AGVs aumentou significativamente.

\subsubsection{Consumo de alimentos}

Schelling (1984), em extenso trabalho de revisão a respeito da monensina, afirmou que os ionóforos deprimem o consumo voluntário de alimentos na ordem de $10,7 \%$, quando os animais são alimentados com dietas predominantemente concentradas, mas podem incrementar o consumo em até $15 \%$, quando em condições de pastejo. Rogers e Davis (1982) explicaram que a diminuição no consumo era provavelmente devido ao aumento do tempo de retenção da matéria seca no rúmen, enquanto que há a possibilidade deste efeito ser devido à ação do ácido propiônico como substância responsável pela regulação da saciedade em ruminantes, a 
semelhança do que acontece com a glicose sangüínea, que regula o consumo de alimentos em animais monogástricos (VAN SOEST, 1983).

A conversão alimentar melhora quando a monensina é adicionada à dieta devido à fermentação ruminal mais eficiente, resultante do aumento da proporção propionato: acetato no rúmen, à concomitante depressão na produção de metano e à inibição na degradação de proteína proveniente da dieta no rúmen (RAUN, 1990).

$\mathrm{O}$ aumento do consumo em animais recebendo dieta predominantemente volumosa seria explicado pelas alterações na digestibilidade da forragem, já que os níveis de ácido propiônico não seriam suficientes para disparar o gatilho da saciedade nessas dietas (SCHELLING, 1984). Estes resultados não estão de acordo com as conclusões de Baile et al. (1979) que afirmaram que os ionóforos reduzem o consumo de alimentos em qualquer tipo de dieta, embora com maiores efeitos em dietas predominantemente concentradas.

A afirmação de Baile et al. (1979) foi confirmada por Ramanzin et al. (1997) que, ao alimentarem vacas com dietas contendo $30 \%$ ou $50 \%$ de concentrados, verificaram que a adição de monensina tendeu a deprimir o consumo de alimentos. Com relação às dietas volumosas, Araujo-Febres e Fernández (1991), ao estudarem os efeitos da monensina em novilhos consumindo dietas com níveis de fibra bruta baixo $(15 \%)$ e alto $(26 \%)$, observaram que a monensina diminuiu o consumo de alimentos em ambas as dietas. Porém, a queda foi maior para a ração com baixo nível de fibra (25,6\% vs. 11,0\%). Ao contrário, McCann et al. (1990) alimentando ovinos 
com dietas contendo $25 \%, 50 \%$ e $75 \%$ de volumosos, registraram que a monensina diminuiu o consumo em $1,6 \%, 12,3 \%$ e $27,0 \%$, respectivamente.

Alert, Poppe e Lohner (1993), adicionando flavomicina à dieta de touros holandeses, observaram que o grupo tratado com flavomicina consumiu significativamente mais alimento que o grupo controle.

Muitos outros trabalhos não observaram efeitos dos antibióticos sobre o consumo de alimentos, entre eles está o de Rodrigues, Lucci e Castro (2000), utilizando diferentes proporções volumoso:concentrados para testar o efeito da lasalocida, o de Zinn, Plascencia e Barajas (1994), utilizando monensina em novilhos submetidos a dietas contendo $10 \%$ ou $20 \%$ de volumosos, e o de Flachowsky e Richter (1991), utilizando diferentes concentrações de flavomicina em carneiros castrados.

\subsubsection{Produção de metano}

A produção de metano pelos ruminantes é influenciada por uma variedade de fatores nutricionais, incluindo o nível de consumo, tipo de carboidrato, processamento da forragem, adição de lipídios e ionóforos na dieta, bem como mudanças na microbiota ruminal (JOHNSON; JOHNSON, 1995).

O metano produzido pela fermentação entérica em ruminantes é responsável por aproximadamente $33-39 \%$ do metano total produzido pelo setor agrícola. Os ionóforos podem reduzir esta produção em $25 \%$ sem afetar o desempenho do animal 
(BENZ; JOHNSON, 1982; TEDESCHI; FOX; TYLUTKI, 2003; VAN NEVEL; DEMEYER, 1996; WEDEGAERTNER; JOHNSON, 1983).

Em estudo in vitro realizado por Baker (1997), a produção de metano, mensurada pela incubação da digesta ruminal, aumentou conforme aumentou a proporção de grãos na dieta. Porém, in vivo (g/dia) a produção de metano diminuiu. Garcia-Lopez, Kung e Odom (1996) demonstraram que a monensina diminuiu a produção de metano em $40 \%$ somente quando o produto foi incubado in vitro, com uma dieta contendo $50 \%$ de concentrados, mas não quando esta possuía $0 \%$ ou $90 \%$ de grãos.

Segundo Baker (1997), quando a taxa de fermentação do rúmen é alta (por exemplo, quando a proporção de grãos na dieta é alta), outras populações microbianas do rúmen podem competir por $\mathrm{H}^{+}$metabólico, causando mudanças no padrão de produção dos AGVs e de metano. Portanto, a explicação para o aumento na produção de metano in vitro $\left(\mathrm{CH}_{4} / \mathrm{mL}\right.$ digesta ruminal $)$, com diminuição na produção de metano in vivo ( $\%$ do consumo de energia bruta), à medida em que a proporção de grãos aumenta na dieta, pode estar relacionada com a capacidade das populações metanogênicas de competir com outras populações microbianas por $\mathrm{H}^{+}$no rúmen.

No estudo in vivo, a monensina diminuiu as produções de metano em 15,6\%, $16,5 \%$ e $23,7 \%$, quando novilhos receberam, respectivamente, níveis de fibra baixo (12\% de FDN), médio ( $27 \%$ de FDN) e alto (40\% de FDN), não sendo observada interação entre a monensina e os níveis de fibra na dieta (THORNTON; OWENS, 
1981). Já Zinn, Plascencia e Barajas (1994) não observaram alteração da produção ruminal de metano com a administração de monensina, quer a dieta possuísse $10 \%$ ou $20 \%$ de volumosos.

McCaughey, Wittenberg e Corrigan (1997) não demonstraram efeito da monensina em diminuir a produção de metano em novilhos sob pastejo.

Nenhum trabalho estudando os efeitos da flavomicina sobre a produção ruminal de metano foi encontrado na literatura.

\subsubsection{Digestibilidade e degradabilidade}

Os ionóforos podem causar pequena à moderada melhora na digestibilidade dos alimentos, dependendo das condições experimentais. Estas condições não estão definidas até o presente momento, podendo sofrer interferência de fatores como consumo de alimentos, enchimento ruminal, taxa de passagem ou outros.

O aumento da digestão dos alimentos obtidos com o emprego de ionóforos tem sido freqüentemente explicado pelo aumento do tempo de retenção da MS no rúmen decorrente do menor consumo voluntário (ROGERS; DAVIS, 1982). Entretanto, Branine e Galyean (1990), ao observarem que a monensina aumentou em 1,4\% a 16,7\% o desaparecimento in situ da MS do alimento em novilhos sob pastejo, provavelmente pelo aumento da degradação da parede celular, explicaram tal fato como sendo decorrente do aumento observado no $\mathrm{pH}$ ruminal e não pela diminuição 
da taxa de passagem pelo pró-ventrículo, sendo que neste experimento foi observado aumento na taxa de passagem de fluídos.

Dentre os diversos fatores que podem alterar os efeitos dos ionóforos sobre a digestibilidade e degradabilidade dos alimentos encontra-se a proporção de fibra na dieta. Pomar et al. (1989), ao alimentarem bezerros e ovelhas com dietas peletizadas contendo $20 \%, 40 \%$ e $60 \%$ de volumosos de alta e média qualidade, observaram que a monensina diminuía a digestibilidade da FDN e FDA em dietas predominantemente concentradas, mas aumentava a digestibilidade destas frações fibrosas em dietas predominantemente volumosas somente em bezerros, mas não em ovelhas, além desses efeitos serem maiores na dieta contendo o volumoso de média qualidade. Os resultados foram explicados por um possível aumento do tempo de retenção da fibra no rúmen, fato esse considerado vantajoso nessas dietas (LEMENAGER et al., 1978). Entretanto, a digestibilidade da MS foi levemente aumentada somente nas rações ricas em volumosos, em contradição com o experimento de McCann et al. (1990) onde, ao alimentarem ovinos com rações contendo $25 \%, 50 \%$ e $75 \%$ de volumosos de baixa qualidade, observou-se que a monensina foi capaz de aumentar a digestibilidade da fibra em detergente neutro e da hemicelulose e apresentou tendência em aumentar a digestibilidade da matéria orgânica a medida em que a proporção de volumosos era diminuída (de 75\% para $25 \%)$.

Outros autores não observaram efeitos dos ionóforos sobre a digestibilidade da MS, conteúdo celular, celulose e hemicelulose em novilhos recebendo níveis de fibra 
baixo $(12,0 \%$ de FDN), médio $(27,0 \%)$ e alto $(40,0 \%)$ na dieta adicionada de monensina (THORNTON; OWENS, 1981). Zinn, Plascencia e Barajas (1994) também não observaram efeitos da monensina sobre a digestibilidade da matéria orgânica, da fibra ou do amido, quer a dieta de novilhos possuísse $10 \%$ ou $20 \%$ de volumosos.

Apesar de vários pesquisadores terem demonstrado efeitos benéficos dos ionóforos sobre a digestibilidade ou degradabilidade dos alimentos, outros não têm demonstrado qualquer efeito, existindo aqueles que reportaram efeitos indesejáveis. Pelo fato do acetato ser o metabólito predominante da digestão microbiana da celulose e sendo que os ionóforos diminuem a proporção molar de acetato, foi antecipado que estes compostos poderiam deprimir a digestão da fibra.

Em 1978, Lemenager et al. registraram que a monensina diminuiu em 12,1\% a digestibilidade in vitro da MS de um volumoso de gramínea de baixa qualidade quando o inóculo era oriundo de animal não adaptado a este produto, mas apenas uma tendência na diminuição deste parâmetro, da ordem de 3,9\%, foi observada quando o inóculo provinha de um animal adaptado. A mesma conclusão pode ser obtida do trabalho de Simpson (1978), o qual observou que a monensina era um potente inibidor da atividade celulolítica in vitro quando o inóculo era obtido de animais não previamente expostos à ela.

Poos, Hanson e Klopfenstein (1979) confirmaram este efeito adaptativo ao observarem diminuição da digestibilidade da MS (6,3 a 11,3\%) e FDA (5,3 a 14,5\%), quando administraram monensina a ovinos durante um período de adaptação de 10 
dias. Porém, ao estenderem este período para 40 dias, estes parâmetros aproximaramse do grupo controle. Em 1979, Chen e Wolin explicaram que algumas bactérias celulolíticas eram moderadamente sensíveis à monensina e/ou à lasalocida e que poderia haver, ainda, rápida seleção de microorganismos ruminais resistentes quando da utilização destes compostos, justificando não somente a diminuição da digestão da fibra, como também o efeito adaptativo.

Outros experimentos têm demonstrado diminuição da digestão da fibra, com o uso de ionóforos, quando realizados in vitro. Whetstone, Davis e Bryant (1981) mostraram que a monensina não alterou a utilização de glicose ou amido pelas bactérias, mas diminuiu a degradação de celulose em 19,4\% a 31,0\%, apesar de não ter alterado o crescimento celular. Bogaërt et al. (1989), utilizando líquido ruminal de carneiros adaptados à lasalocida ou catiomicina durante 30 dias, observaram que a degradação da celulose foi $12 \%$ maior para o grupo controle. Entretanto, alguns experimentos realizados in vivo, foram capazes de demonstrar apenas uma tendência dos ionóforos em diminuir a digestão da fibra (FREDRICKSON et al., 1993; LEMENAGER et al., 1978).

Esses achados encorajaram Bogaërt, Gomez e Jouany (1991) a sugerir que a diminuição da degradação da fibra, observada em experimentos in vitro, poderia advir de uma alteração na composição da microbiota populacional decorrente das altas doses de ionóforos utilizadas nestes experimentos, fato esse não observado in vivo, onde estes aditivos apenas causariam uma modificação no metabolismo celular dos microorganismos ruminais. 
A dosagem ou concentração do ionóforo também interfere nos resultados, fato esse demonstrado por Faulkner et al. (1985) que, ao alimentarem bovinos adaptados à monensina e recebendo uma dieta rica em fibras, observaram uma resposta quadrática para a digestibilidade da matéria orgânica e FDN, com melhores resultados para dosagens intermediárias de monensina (100mg/animal/dia) em relação a altos níveis $(200 \mathrm{mg} / \mathrm{animal} / \mathrm{dia})$ ou controle $(0 \mathrm{mg} / \mathrm{animal} / \mathrm{dia})$, concluindo que a dose de $200 \mathrm{mg} /$ animal/dia é bastante alta para animais submetidos a dietas ricas em fibra.

Já para a flavomicina, Flachowsky e Richter (1991) verificaram que este antibiótico não teve influência significativa na digestibilidade da matéria orgânica e de outros nutrientes, bem como nos parâmetros de fermentação ruminal, quando testou vários níveis de flavomicina $(0,5$ e $10 \mathrm{mg} / \mathrm{animal} / \mathrm{dia})$ em carneiros castrados, recebendo dieta volumosa. Entretanto, para touros em confinamento, a administração de flavomicina aumentou a digestibilidade aparente da matéria orgânica, fibra bruta e do extrativo não nitrogenado (ALERT; POPPE; LOHNER, 1993; POPPE et al., 1993).

\subsubsection{Utilização da proteína}

Vários trabalhos têm demonstrado efeitos benéficos dos ionóforos sobre a utilização da proteína pelo animal e várias são as teorias que tentam explicar tal efeito. Alguns trabalhos, particularmente com monensina, observaram diminuição da 
proteólise no rúmen em conseqüência à inibição do crescimento bacteriano. Poos, Hanson e Klopfenstein (1979) observaram diminuição no nitrogênio de origem bacteriana e aumento no de origem vegetal que chegava ao abomaso. Faulkner et al. (1985) relataram diminuição da degradação protéica e/ou síntese de proteína bacteriana no rúmen, enquanto que Rodriguez, Craig e Hembry (1986) observaram diminuição dos níveis extracelulares de amônia contida na fase líquida do conteúdo ruminal sem alteração dos níveis de aminoácidos. Chen e Russell (1991) relataram que a monensina apresentou maior ação em inibir a deaminação do que a proteólise no rúmen, devido ao acúmulo de nitrogênio amoniacal e peptídios. Gomez et al. (1991) relataram diminuição no fluxo de nitrogênio microbiano e aumento no fluxo de nitrogênio da proteína não degradada oriunda da dieta com a utilização de ionóforos.

Russell, Strobel e Chen (1988), ao isolarem um novo grupo de bactérias Gram positivas que produzia 20 vezes mais amônia e que era sensível à monensina, concluíram que os efeitos protetores dos ionóforos sobre as proteínas poderiam ser explicados pela sua atividade contra bactérias que fermentavam peptídios e aminoácidos.

Chen e Russell (1991) vieram a reafirmar esta idéia ao mostrar que a inibição de bactérias Gram negativas e positivas através do TCS (3,3', 4',5tetraclorosalicilanida), um protonóforo que inibe esses dois grupos de bactérias, não causava maior diminuição nos níveis de amônia que a monensina, a qual é primariamente efetiva contra bactérias Gram positivas. Posteriormente foi demonstrado que esta cepa era a única bactéria ruminal sensível à monensina e que 
poderia fermentar lisina, desde que este aminoácido estivesse em altos níveis (VAN KESSEL; RUSSELL, 1992).

Outros experimentos trazem dados ainda mais intrigantes quanto aos efeitos dos ionóforos sobre a utilização das proteínas. Yang e Russell (1993), ao alimentarem vacas não-lactantes com feno e diferentes níveis de farelo de soja, observaram que a administração de monensina diminuía em $30 \%$ os níveis ruminais de amônia, acompanhada de diminuição similar na atividade específica de produção desta amônia (nmol de amônia/mg de proteína/minuto). Este fato foi concomitante à diminuição em 10 vezes no número das bactérias que poderiam utilizar peptídios e aminoácidos, ao invés de carboidratos, como fonte de energia. Apesar da monensina não ter aumentado os níveis de proteína solúvel, peptídios e aminoácidos no líquido ruminal, ela aumentou a concentração de proteína bacteriana.

Concluiu-se que peptídeos e aminoácidos, protegidos da deaminação, foram convertidos em proteína microbiana por cepas resistentes ao ionóforo, o que poderia prover fluxo adicional de nitrogênio de origem bacteriana para o trato digestivo posterior, ao invés de nitrogênio de origem dietética. Tais resultados foram confirmados por Lana e Russell (1997).

Estes achados sugerem que uma grande parte da proteína verdadeira da dieta pode passar direto pelo rúmen quando a monensina é adicionada (FAULKNER et al., 1985). Em média, a adição de monensina aumentou a digestibilidade do nitrogênio em 3,5\% em bovinos (SPEARS, 1990). 
Tão importantes quanto a causa metabólica, responsável pela melhora na utilização da proteína ocasionada pelos ionóforos, são os diversos fatores que alteram esta resposta, mas nem por isso os resultados são menos conflitantes. AraujoFebres e Fernández (1991), ao estudarem os efeitos da monensina em novilhos submetidos à dietas com $15 \%$ ou $26 \%$ de fibra bruta durante 42 dias, observaram aumento da digestibilidade da proteína bruta em $2,7 \%$ para a dieta alta em fibra e significativamente maior, na ordem de $32,7 \%$, para a dieta baixa em fibra.

Estes dados concordam com os obtidos por McCann et al. (1990) que, ao alimentarem ovinos com dietas contendo $25 \%, 50 \%$ e $75 \%$ de volumosos, observaram que a monensina melhorou a digestibilidade do nitrogênio em 11,8\% somente em animais recebendo dietas com $25 \%$ de volumoso e quando este era tratado com NaOH. Zinn, Plascencia e Barajas (1994) observaram que a monensina aumentava a quantidade de nitrogênio microbiano que chegava ao abomaso e diminuía o nitrogênio de origem dietária, independente se os animais recebessem $10 \%$ ou $20 \%$ de volumosos na dieta. Entretanto, nenhum efeito foi observado sobre a digestão total do nitrogênio.

Dada a variabilidade das respostas obtidas com a utilização de ionóforos, vários trabalhos não apresentaram resultados estatisticamente significativos. Sip e Pritchard (1991), ao alimentarem novilhos com dietas constituídas por 80\% de concentrados e diferentes níveis protéicos $(90 \%, 100 \%, 110 \%$ e $120 \%$ das exigências), não observaram interações entre o nível de monensina e o de $\mathrm{PB}$ da dieta sobre o desempenho animal, atribuindo o aumento na resposta obtida com a 
monensina $(7,6 \%$ no ganho de peso diário) à melhora no metabolismo energético $\mathrm{e}$ não ao seu efeito protéico-protetor, o que foi, ainda, substanciado pelo fato da monensina não ter provocado nenhum efeito nas concentrações plasmáticas de uréia.

Antibióticos não-ionóforos, como a avoparcina e a flavomicina, mostraram aumentar a absorção de aminoácidos no intestino delgado (MACGREGOR; ARMSTRONG, 1984). É possível que a ação da flavomicina seja no rúmen e/ou no intestino delgado, diminuindo a degradação de aminoácidos. Por outro lado, a redução na atividade microbiana no intestino delgado pode resultar em efeito benéfico na parede intestinal, aumentando a eficiência absortiva (MURRAY; ROWE; AITCHISON, 1990). Acredita-se que a flavomicina tenha ação principalmente pósruminal (ROWE; MORELL; BROOME, 1982), embora também tenha influência na função ruminal de maneira similar aos outros ionóforos sob algumas condições (AITCHISON; RALPH; ROWE, 1989; AITCHISON; TANAKA; ROWE, 1989).

Fébel, Fekete e Romvari (2001) relataram que a salinomicina, outro nãoionóforo, inibiu a proteólise e reduziu a eficiência da síntese de proteína microbiana. O efeito da salinomicina no metabolismo do nitrogênio foi independente da composição do substrato. Diferentemente da salinomicina, a flavomicina tendeu a aumentar a proteólise no rúmen e não inibiu a síntese de proteína.

No entanto, Poppe et al. (1993), ao realizarem experimento com touros holandeses, observaram que a síntese de proteína microbiana no rúmen, após a adição de flavomicina, foi levemente reduzida, bem como a taxa de degradação da proteína dietária. 


\subsubsection{Volume ruminal e taxa de passagem}

Pesquisas realizadas por Lemenager et al. (1978), em novilhos recebendo dieta à base de $70 \%$ de volumoso de baixa qualidade, demonstraram que a monensina diminuiu a taxa de passagem sólida e o volume líquido ruminal em 43,6\% e $26,2 \%$, respectivamente, e apresentou tendência em diminuir a taxa de passagem de líquidos em $30,8 \%$. Porém, nenhum efeito foi observado sobre o enchimento ruminal de MS. Ao utilizarem dietas predominantemente concentradas, a monensina diminuiu significativamente a taxa de passagem de líquidos em 9,6\% a 22,0\%.

Da mesma forma, ao alimentarem ovinos com dieta contendo $66,7 \%$ de volumosos adicionada de lasalocida ou monensina, Ricke et al. (1984) também observaram que esses aditivos tenderam a diminuir a taxa de passagem de sólidos em $13,0 \%$ e $15,2 \%$ e de líquidos em 5,9\% e 9,8\%, respectivamente, sem, contudo, causarem alterações sobre o volume líquido ruminal.

Entretanto, Rogers e Davis (1982) mostraram que a monensina não alterou o volume líquido ruminal, a taxa de passagem de líquidos pelo rúmen, o fluxo total de líquidos e o fluxo total de líquidos por quilo de MS consumida em novilhos alimentados com dieta composta de 50\% de volumoso.

Como observado no experimento de Lemenager et al. (1978), a taxa de passagem de líquidos seria diminuída em virtude de marcante redução na ingestão de água e no fluxo salivar decorrente da menor ingestão. Essa diminuição na ingestão de 
alimentos permitiria aumento no tempo de retenção da matéria seca no rúmen, a qual seria em grande parte responsável pelos efeitos dos ionóforos. Essa hipótese é substanciada por outros trabalhos onde os ionóforos não alteraram os parâmetros de dinâmica ruminal (BOGAËRT; GOMEZ; JOUANY, 1991; FREDRICKSON et al., 1993; GALLOWAY et al., 1993; KNOWLTON; ALLEN; ERICKSON, 1996; POOS; HANSON; KLOPFENSTEIN, 1979; RODRIGUES; LUCCI; CASTRO, 2000; RODRIGUEZ; CRAIG; HEMBRY, 1986; YANG; RUSSELL, 1993).

Em experimento utilizando diferentes concentrações de flavomicina, observou-se aumento do tempo de retenção necessário para o animal consumir toda sua ração diária, podendo ser indicativo de diminuição na taxa de passagem da digesta através do trato digestivo, permitindo maior aumento na eficiência absortiva (MURRAY; ROWE; AITCHISON, 1990).

\subsubsection{Outras ações}

Tem sido demonstrado que os ionóforos apresentam possibilidade de menor incidência de edema e enfisema pulmonar em bovinos (SCHELLING, 1984), efeito anticetogênico em vacas leiteiras (DUFFIELD et al., 1998; SAUER; KRAMER; CANTWELL, 1989), sem alterar a produção ou composição do leite (SAUER; KRAMER; CANTWELL, 1989), diminuição da incidência de desordens digestivas, como o timpanismo (BRANINE; GALYEAN, 1990) e a acidose em ruminantes (MCGUFFEY; RICHARDSON; WILKINSON, 2001), diminuição no número e 
capacidade de sobrevivência de pupas de mosca do chifre nas fezes de bovinos (HERALD et al., 1982) e alteração do status mineral (REFFETT-STABEL et al., 1989) e lipídico (MAROUNEK; PETR; MACHAÑOVÁ, 1990) dos animais, diminuindo inclusive a lipólise (VAN NEVEL; DEMEYER, 1995), a biohidrogenação ruminal (FELLNER; SAUER; KRAMER, 1997) ou a proporção de ácidos graxos saturados no leite (SAUER et al., 1997). 


\section{REFERÊNCIAS}

AITCHISON, E. M.; RALPH, I. G.; ROWE, J. B. Evaluation of feed additives for increasing wool production from Merino sheep. 1. Lasalocid, avoparcin and flavomycin included in lucerne-based pellets or oaten chaff fed at maintenance. Australian Journal of Experimental Agriculture, v. 29, p. 321-325, 1989.

AITCHISON, E. M.; TANAKA, K.; ROWE, J. B. Evaluation of feed additives for increasing wool production from Merino sheep. 2. Flavomycin and tetronasin included in lucerne-based pellets or wheaten chaff fed ad libitum. Australian Journal of Experimental Agriculture, v. 29, p. 327-332, 1989.

ALERT, H. J.; POPPE, S.; LOHNER, M. The effect of flavomycin on the fattening performance of bulls. Arch Tierernahr, v. 43, n. 4, p. 371-380, 1993.

ARAUJO-FEBRES, O.; FERNÁNDEZ, M. C. Efecto en novillos del monensin y el nivel de fibra de la dieta sobre el consumo y la digestibilidad de la materia seca.

Revista de la Facultad de Agronomía, v. 8, n. 2, p. 143-153, 1991.

BAILE, C. A.; MCLAUGHLIN, C. L.; POTTER, E. L.; CHALUPA, W. Feeding behavior changes of cattle during introduction of monensin with roughage or concentrate diets. Journal of Animal Science, v. 48, n. 6, p. 1501-1508, 1979.

BAKER, S. K. Gut microbiology and its consequences for the ruminant.

Proceedings of the Nutrition Society, v. 21, p. 6-13, 1997.

BARRAGRY, T. B. Growth-promoting agents. In: Veterinary drug therapy. Philadelphia: L\&A e Febiger, 1994, p. 597-654.

BENZ D. A.; JOHNSON, D. A. The effect of monensin on energy partitioning by forage feed steers. Journal of Animal Science, v. 55, p. 491, 1982. Suplemento 1.

BERGEN, W. G.; BATES, D. B. Ionophores: Their effect on production efficiency and mode of action. Journal of Animal Science, v. 58, n. 6, p. 1465-1483, 1984.

BOGAËRT, C.; GOMEZ, L.; JOUANY, J. P. Effects of lasalocid and cationomycin on the digestion of plant cell walls in sheep. Canadian Journal of Animal Science, v. 71, n. 2, p. 379-388, 1991. 
BOGAËRT, C.; GOMEZ, L.; JOUANY, J. P.; JEMINET, G. Effects of the ionophore antibiotics lasalocid and cationomycin on ruminal fermentation in vitro (RUSITEC). Animal Feed Science and Technology, v. 27, p. 1-15, 1989.

BRANINE, M .E.; GALYEAN, M. L. Influence of grain and monensin supplementation on ruminal fermentation, intake, digesta kinetics and incidence and severity of frothy bloat in steers grazing winter wheat pasture. Journal of Animal Science, v. 68, n. 3, p. 1139-1150, 1990.

CHEN, G.; RUSSELL, J. B. Effect of monensin and a protonophore on protein degradation, peptide accumulation, and deamination by mixed ruminal microorganisms in vitro. Journal of Animal Science, v. 69, n. 5, p. 2196-2203, 1991.

CHEN, M.; WOLIN, M. F. Effect of monensin and lasalocid-sodium on the growth of methanogenic and saccharolytic bacteria. Applied Environmental Microbiology, v. 38, n. 1, p. 72-77, 1979.

DUFFIELD, T. F.; SANDALS, D.; LESLIE, K. E.; LISSEMORE, K.; MCBRIDE, B. W.; LUMSDEN, J. H.; DIKC, P.; BAGG, R. Efficacy of monensin for the prevention of subclinical ketosis in lactating dairy cows. Journal of Dairy Science, v. 81, n. 11, p. 2866-2873, 1998.

EDWARDS, J. E.; MCEWAN, N. R.; MCKAIN, N.; WALKER, N.; WALLACE, R. $\mathrm{J}$. Influence of flavomycin on ruminal fermentation and microbial populations in sheep. Microbiology, v. 151, n. 3, p. 717-725, 2005.

FAULKNER, D. B.; KLOPFENSTEIN, T. J.; TROTTER, N. T.; BRITTON, R. A. Monensin effects on digestibility, ruminal protein escape and microbial protein synthesis on high-fiber diets. Journal of Animal Science, v. 61, n. 3, p. 654-660, 1985.

FÉBEL, H.; FEKETE, S.; ROMVARI, R. Comparative investigation of salinomycin and flavophospholipol in sheep fed different composed diets. Arch Tierernahr, v. 54, n. 3, p. 225-242, 2001.

FÉBEL, H.; SZELÉNYI, M.; JÉCSAI, J.; JUHÁSZ, B. Effect of salinomycin, flavomycin and avoparcin on some physiological traits of growing lambs, with particular respect to rumen fermentation. Acta Veterinaria Hungarica, v. 36, n. 1-2, p. 69-80, 1988.

FELLNER, V.; SAUER, F. D.; KRAMER, J. K. G. Effect of nigericin, monensin, and tetronasin on biohydrogenation in continuous flow-through ruminal fermenters. Journal of Dairy Science, v. 80, n. 5, p. 921-928, 1997. 
FLACHOWSKY, G.; RICHTER, G. H. Effect of flavomycin on the apparent digestibility of crude nutrients in wethers, parameters of rumen fermentation in cattle and feed intake and weight gain of heifers. Arch Tierernahr, v. 41, n. 3, p. 303-310, 1991.

FREDRICKSON, E. L.; GALYEAN, M. L.; BRANINE, M. E.; SOWELL, B.; WALLACE, J. D. Influence of ruminally dispensed monensin and forage maturity on intake and digestion. Journal of Range Managment, v. 46, n. 3, p. 214-220, 1993.

GALLOWAY, D. L.; GOETSCH, A. L.; PATIL, A.; FORSTER Jr., L. A.;

JOHNSON, Z. B. Feed intake and digestion by Holstein steer calves consuming lowquality grass supplemented with lasalocid or monensin. Canadian Journal of Animal Science, v. 73, n. 4, p. 869-879, 1993.

GARCIA-LOPEZ, P. M.; KUNG, L.; ODOM, J. M. In vitro inhibition of microbial methane production by 9,10-Anthraquinone. Journal of Animal Science, v. 74, n. 9, p. 2276-2284, 1996.

GOMEZ, L.; BOGAËRT, C.; JOUANY, J. P.; LASSALAS, B. The influence of lasalocid and cationomycin on nitrogen digestion in sheep: Comparison of methods for estimating microbial nitrogen. Canadian Journal of Animal Science, v. 71, n. 2, p. 389-399, 1991.

GREEN, B. L.; MCBRIDE, B. W.; SANDALS, D.; LESLIE, K. E.; BAGG, R.; DICK, P. The impact of a monensin controlled-release capsule on subclinical ketosis in the transition dairy cow. Journal of Dairy Science, v. 82, n. 2, p. 333-342, 1999.

HERALD, F.; KNAPP, F. W.; BROWN, S.; BRADLEY, N. W. Efficacy of monensin as a cattle feed additive against the face fly and horn fly. Journal of Animal Science, v. 54, n. 6, p. 1128-1131, 1982.

JOHNSON, K. A.; JOHNSON, D. E. Methane emissions from cattle. Journal of Animal Science, v. 73, n. 8, p. 2483-2492, 1995.

KNOWLTON, K. F.; ALLEN, M. S.; ERICKSON, P. S. Lasalocid and particle size of corn for dairy cows in early lactation. 2. Effect on ruminal measurements and feeding behavior. Journal of Dairy Science, v. 79, n. 4, p. 565-574, 1996.

LANA, R. P.; RUSSELL, J. B. Effect of forage quality and monensin on the ruminal fermentation of fistulated cows fed continuously at a constant intake. Journal of Animal Science, v. 75, n. 1, p. 224-229, 1997. 
LEMENAGER, R. P.; OWENS, F. N.; SHOCKEY, B. J.; LUSBY, K. S.;

TOTUSEK, R. Monensin effects on rumen turnover rate, twenty-four hour VFA pattern, nitrogen components and cellulose disappearance. Journal of Animal Science, v. 47, n. 1, p. 255-261, 1978.

MAROUNEK, M.; PETR, O; MACHAÑOVÁ, L. Effect of monensin on in vitro fermentation of maize starch by hindgut contents of cattle. Journal of Agricultural Science, v. 115, p. 389-392, 1990.

MAROUNEK, M.; DUŠKOVÁ, D.; SKŘIVANOVÁ, V. Effect of non-ionophore feed antibiotics on in vitro fermentation in the ovine rumen and rabbit caecum. Journal of Agricultural Science, v. 130, n. 1, p. 115-118, 1998.

MCCANN, M. A.; CRADDOCH, B. F.; PRESTON, R. L.; RANSEY, C. B. Digestibility of cotton plant by-products diets for sheep at two levels of intake. Journal of Animal Science, v. 68, n. 2, p. 285-295, 1990.

MCCAUGHEY, W. P.; WITTENBERG, K.; CORRIGAN, D. Methane production by steers on pasture. Canadian Journal of Animal Science, v. 77, n. 3, p. 519-524, 1997.

MACGREGOR, R. C.; ARMSTRONG, D. G. The feed antibiotic avoparcin and net uptake of amino acids from the small intestine of sheep. Canadian Journal of Animal Science, v. 64, p. 134-135, 1984. Suplemento.

MCGUFFEY, R. K.; RICHARDSON, L. F.; WILKINSON, J. I. D. Ionophores for dairy cattle: Current status and future outlook. Journal of Dairy Science, v. 84, p. 194-203, 2001. Suplemento E.

MURRAY, P. J.; ROWE, J. B.; AITCHISON, E. M. The effect of bentonite on wool growth, liveweight change and rumen fermentation in sheep. Australian Journal of Experimental Agriculture, v. 30, p. 39-42, 1990.

MURRAY, P. J.; ROWE, J. B.; SPEIJERS, E. J. Sulfur supplementation and the use of flavomycin with lupin grain for sheep. Australian Journal of Experimental Agriculture, v. 42, p. 1323-1333, 1991.

NAGARAJA, T. G.; NEWBOLD, C. J.; VAN NEVEL, C. J.; DEMEYER, D. I. Manipulation of ruminal fermentation. In: 2.ed., New York: Blackie, 1997. p. 523-532. The rumen microbial ecosystem, 
OVCHINNIKOV, Y. A. Physico-chemical basis of ion transport through biological membranes: Ionophores and ion channels. European Journal of Biochemistry, v. 94, p. 321-336, 1979.

POMAR, C.; BERNIER, J. F.; SEOANE, F. R.; LATRILLE, L. High-roughage rations with or without monensin for veal production. 2. Ration digestibility. Canadian Journal of Animal Science, v. 69, n. 2, p. 403-410, 1989.

POOS, M. I.; HANSON, T. L.; KLOPFENSTEIN, T. J. Monensin effects on diet digestibility, ruminal protein bypass and microbial protein synthesis. Journal of Animal Science, v. 48, n. 6, p. 1516-1524, 1979.

POPPE, S.; ALERT, H. J.; MEIER, H.; LOHNER, H. The effect of flavomycin on digestion in fattening bulls. Arch Tierernahr, v. 43, n. 4, p. 363-369, 1993.

PRESSMAN, B. C. Biological applications of ionophores. Annual Review Biochemistry, v. 45, p. 501-530, 1976.

RAMANZIN, M.; BAILONI, L.; SCHIAVON, S.; BITTANTE, G. Effect of monensin on milk production and efficiency of dairy cows fed two diets differing in forage to concentrate ratios. Journal of Dairy Science, v. 80, n. 6, p. 1136-1142, 1997.

RAUN, A. P. Rumensin "then and now". In: Rumensin in the 1990's. Denver: Elanco Animal Health, 1990. p. 1-20. Suplemento A.

REFFETT-STABEL, J.; SPEARS, J. W.; HARVEY, R. W.; LUCAS, D. M. Salinomycin and lasalocid effects on growth rate, mineral metabolism and ruminal fermentation in steers. Journal of Animal Science, v. 67, n. 10, p. 2735-2742, 1989.

RICHARDSON, L. F.; RAUN, A. P.; POTTER, E. L.; COOLEY, C. O. Effect of monensin in rumen fermentation in vitro and in vivo. Journal of Animal Science, v. 43, n. 3, p. 657-664, 1976.

RICKE, S. C.; BERGER, L. L.; VAN DER AAR, P. J.; FAHEY, G. C. Effects of lasalocid and monensin on nutrient digestion, metabolism and rumen characteristics of sheep. Journal of Animal Science, v. 58, n. 1, p. 194-202, 1984.

RODRIGUES, P. H. M.; LUCCI, C. S.; CASTRO, A. L. Efeitos da lasalocida sódica e proporção volumoso/concentrados sobre a fermentação ruminal em vacas secas. Brazilian Journal of Veterinary Research and Animal Science, v. 37, n. 3, p. 253-258, 2000. 
RODRIGUEZ, S. L.; CRAIG, W. M.; HEMBRY, F. G. Changes in ruminal concentrations of microbial ammonia and amino acids due to monensin and time. Journal of Animal Science, v. 63, n. 6, p. 1990-1995, 1986.

ROGERS, J. A.; DAVIS, C. L. Rumen volatile fatty acid production and nutrient utilization in steers fed a diet supplemented with sodium bicarbonate and monensin. Journal of Dairy Science, v. 65, n. 6, p. 944-952, 1982.

ROWE, J. B.; MORELL, J. S. W.; BROOME, A. W. J. Flavomycin as a ruminant growth promoter - investigation of the mode of action. Proceedings of the Nutrition Society, v. 41, p. 56A, 1982.

RUSSELL, J. B.; ONODERA, R.; HINO, T. Ruminal protein fermentation: New perspectives on previous contradictions. In: Physiological aspects of digestion and metabolism in ruminants. San Diego: Academic Press, 1991. p. 682-697.

RUSSELL, J. B.; STROBEL, H. J.; CHEN, G. Enrichment and isolation of a ruminal bacterium with a very high specific activity of ammonia production. Applied Environmental Microbiology, v. 54, n. 4, p. 872-877, 1988.

SAUER, F. D.; FELLNER, V.; KINSMAN, R.; KRAMER, J. K. G.; JACKSON, H. A.; LEE, A. J.; CHEN, S. Methane output and lactation response in Holstein cattle with monensin or unsaturated fat added to the diet. Journal of Animal Science, v. 76, n. 3, p. 906-914, 1997.

SAUER, F. D.; KRAMER, J. K.; CANTWELL, W. J. Antiketogenic effect of monensin in the early lactancy. Journal of Dairy Science, v. 72, n. 2, p. 436-442, 1989.

SCHELLING, G. T. Monensin mode of action in the rumen. Journal of Animal Science, v. 58, n. 6, p. 1518-1527, 1984.

SIMPSON, M. E. Effects of certain antibiotics in vitro cellulose digestibility and volatile fatty acid (VFA) production by ruminal microorganisms. Journal of Animal Science, v. 47, p. 429, 1978. Suplemento 1.

SIP, M. L.; PRITCHARD, R. H. Nitrogen utilization by ruminants during restricted intake of high-concentrate diets. Journal of Animal Science, v. 69, n. 6, p. 26552662, 1991.

SPEARS, J. W. Ionophores and nutrient digestion and absorption in ruminants. Journal of Nutrition, v. 120, n. 6, p. 632-638, 1990. 
TEDESCHI, L. O.; FOX, D. G.; TYLUTKI, T. P. Potential environment benefits of ionophores in ruminant diets. Journal of Environmental Quality, v. 32, n. 5, p. 1591-1602, 2003.

THORNTON, J. H.; OWENS, F. N. Monensin supplementation and in vivo methane production by steers. Journal of Animal Science, v. 52, n. 3, p. 628-634, 1981.

VAN DER MERWE, B. J.; DUGMORE, T. J.; WALSH, K. P. The effect of flavophospholipol (Flavomycin) on milk production and milk urea nitrogen concentrations of grazing dairy cows. South Africa Journal of Animal Science, v. 31, n. 2, p. 101-105, 2001.

VAN HEIJENOORT, J. Formation of the glycan chains in the synthesis of bacteria peptidoglycan. Glycobiology, v. 11, p. 25-36, 2001. Suplemento R.

VAN KESSEL, J. S.; RUSSELL, J. B. Energetics of arginine and lysine transport by whole cells and membrane vesicles of strain SR, a monensin-sensitive ruminal bacterium. Applied Environmental Microbiology, v. 58, n. 3, p. 969-975, 1992.

VAN MAANEN, R. W.; HERBEIN, J. H.; MCGILLIARD, A. D.; YOUNG, J. W. Effects of monensin in vivo rumen propionate production and blood glucose kinetics in cattle. Journal of Nutrition, v. 108, n. 6, p. 1002-1007, 1978.

VAN NEVEL, C. J.; DEMEYER, D. I. Lipolysis and biohydrogenation of soybean oil in the rumen in vitro: inhibition by antimicrobials. Journal of Dairy Science, v. 78, n. 12, p. 2797-2806, 1995.

VAN NEVEL, C. J.; DEMEYER, D. I. Control of rumen methanogenesis. Environmental Monitoring and Assessment, v. 42, n. 1-2, p. 77-101, 1996.

VAN SOEST, P. J. Nutritional Ecology of the Ruminant. USA: O \& B Books, Inc., 1983. 674p.

WEDEGAERTNER, T. C.; JOHNSON, D. E. Monensin effects on digestion, methanogenesis and heat increment of a cracked corn-silage diet fed to steers. Journal of Animal Science, v. 57, n. 1, p. 168-177, 1983.

WHETSTONE, H. D.; DAVIS, C. L.; BRYANT, M. P. Effect of monensin on breakdown of protein by ruminal microorganisms in vitro. Journal of Animal Science, v. 53, n. 3, p. 803-809, 1981. 
YANG, C. M. J.; RUSSELL, J. B. The effect of monensin supplementation on ruminal ammonia accumulation in vivo and the numbers of amino acid-fermenting bacteria. Journal of Animal Science, v. 71, n. 12, p. 3470-3476, 1993.

ZINN, R. A; PLASCENCIA, A.; BARAJAS, R. Interaction of forage level and monensin in diets for feedlot cattle on growth performance and digestive function. Journal of Animal Science, v. 72, n. 9, p. 2209-2215, 1994. 


\section{CAPÍTULO III}

\section{EFEITOS DA FLAVOMICINA OU DA MONENSINA SOBRE A FERMENTAÇÃO RUMINAL EM BOVINOS}

\section{INTRODUÇÃO}

É amplamente aceito que a administração controlada de certos antibióticos pode ser benéfica para ruminantes, suínos e aves. Desde de que se começou a utilizar antibióticos na alimentação animal, acredita-se que a melhora no desempenho do animal seja devido à ação antimicrobiana na microbiota gastro-intestinal (PARKER; ARMSTRONG, 1987).

Em ruminantes, vários tipos de agentes químicos e antibióticos têm sido desenvolvidos com a finalidade de modificar a digestão fermentativa e o fluxo de nutrientes do rúmen (CHALUPA, 1977). Os produtos mais utilizados hoje em dia para ruminantes são os ionóforos e, em menor escala, alguns antibióticos nãoionóforos. São poucas as informações disponíveis sobre o efeito dos antibióticos nãoionóforos utilizados na alimentação de ruminantes. Tais antibióticos representam um grupo diversificado, apresentando diferenças em sua composição química, espectro antibacteriano, modo de ação da inibição bacteriana, peso molecular e capacidade de 
absorção pelo intestino delgado. A avoparcina, flavomicina, tilosina e virginamicina melhoram o crescimento do animal, modificando a característica fermentativa do rúmen (NAGARAJA et al., 1997).

A flavomicina é um antibiótico fosfoglicolipídico que tem sido usado exclusivamente como promotor de crescimento anti-bacteriano. No entanto, tal mecanismo de promoção do crescimento, em ruminantes, ainda não está claro. Seu modo de ação na população microbiana do rúmen parece diferir dos ionóforos já conhecidos (FÉBEL et al., 1988).

Diversos autores (CHEN; RUSSELL, 1991; DENNIS; NAGARAJA; BARTLEY, 1981; DUFFIELD et al., 1998; FUNK; GALYEAN; ROSS, 1986; MCGUFFEY; RICHARDSON; WILKINSON, 2001; MCKAIN et al., 2000; PHIPPS et al., 2000; OVCHINNIKOV, 1979; SCHELLING, 1984) têm buscado caracterizar a ação dos antimicrobianos e esclarecer como esses agentes atuam para melhorar a eficiência digestiva e, conseqüentemente, a produtividade dos animais. O objetivo do presente estudo foi caracterizar os efeitos da administração da flavomicina, em comparação com a monensina sódica, sobre a fermentação ruminal e consumo de matéria seca em bovinos. 
O trabalho foi conduzido nas dependências do Departamento de Nutrição e Produção Animal da Faculdade de Medicina Veterinária e Zootecnia da Universidade de São Paulo (Campus de Pirassununga).

Foram utilizadas doze fêmeas bovinas mestiças, não lactantes e não gestantes, portadoras de fístulas ruminais, que possuíam em média $736 \mathrm{~kg}$ de peso vivo ao início do experimento. O estábulo utilizado possuía baias individuais, com cochos de cimento, bebedouros automáticos, piso emborrachado e ventiladores suspensos no teto, que eram ligados nas horas mais quentes do dia. O delineamento experimental foi o inteiramente casualizado com três tratamentos, correspondendo ao controle negativo (ausência de antibiótico), tratado (flavomicina) e controle positivo (monensina sódica). Para o tratamento com flavomicina foi utilizada a dose de 20mg/animal/dia (250mg de produto comercial/animal/dia). Para o tratamento com monensina foi utilizado o produto comercial Rumensin ${ }^{\circledR}$ (Elanco), na dose de 300mg de monensina sódica/animal/dia. Cada produto foi pesado separadamente em balança analítica e depois acondicionado em envelopes confeccionados em papel absorvente. Estes foram administrados diariamente no interior do rúmen, através da fístula ruminal, durante o momento das refeições e misturados ao conteúdo ruminal por meio de agitação manual. Os animais foram alimentados duas vezes ao dia, às 8:00h e 16:00h, exceto no $21^{\circ}$ dia, onde a segunda alimentação do dia foi fornecida somente quando encerradas as colheitas de líquido ruminal, ou seja, às 20:00h. A 
dieta continha $60 \%$ de concentrados e $40 \%$ de volumoso (Tabela 1 ), sendo fornecida na forma de mistura completa, permitindo-se $10 \%$ de sobras. 
Tabela 1 - Proporções de ingredientes utilizados e composição bromatológica das rações, com base na matéria seca.

Tabela 1 - Ingredients and chemical composition of diets (DM basis)

\begin{tabular}{|c|c|}
\hline $\begin{array}{l}\text { Ingredientes }(\%) \\
\text { Ingredients }(\%)\end{array}$ & $\begin{array}{l}\text { Proporção } \\
\text { Proportion }\end{array}$ \\
\hline $\begin{array}{l}\text { Cana-de-açúcar } \\
\text { Sugar cane }\end{array}$ & 40,0 \\
\hline Grãos de milho moído & 39,8 \\
\hline Corn grain, ground & \\
\hline $\begin{array}{l}\text { Farelo de soja } \\
\text { Sovbean, meal }\end{array}$ & 18,4 \\
\hline Calcário calcítico & 0,30 \\
\hline $\begin{array}{l}\text { Sal branco }(\mathrm{NaCl}) \\
\text { White salt }(\mathrm{NaCl})\end{array}$ & 0,50 \\
\hline Mistura mineral $^{1}$ & 1,00 \\
\hline Mineral mixture & 100,00 \\
\hline & $\begin{array}{c}\text { Composição } \\
\text { Composition }\end{array}$ \\
\hline $\begin{array}{l}\mathrm{MS}(\%) \\
D M(\%)\end{array}$ & 44,31 \\
\hline $\begin{array}{l}\mathrm{PB}(\%) \\
C P(\%)\end{array}$ & 14,76 \\
\hline $\begin{array}{l}\text { Proteína degradável }(\% \text { da } \mathrm{PB})^{2} \\
\text { Rumen degradable protein }(\% \text { of } C P)\end{array}$ & 64,50 \\
\hline Proteína não degradável $(\% \text { da } \mathrm{PB})^{2}$ & 35,50 \\
\hline Rumen undegradable protein (\% of CP) & \\
\hline $\begin{array}{l}\text { FDA }(\%) \\
A D F(\%)\end{array}$ & 22,16 \\
\hline $\begin{array}{l}\text { FDN }(\%) \\
N D F(\%)\end{array}$ & 29,67 \\
\hline $\begin{array}{l}\mathrm{EE}(\%) \\
E E(\%)\end{array}$ & 2,24 \\
\hline $\begin{array}{l}\text { Energia Líq. Lact. (Mcal } / \mathrm{kg})^{2} \\
N E_{L}(\mathrm{Mcal} / \mathrm{kg})\end{array}$ & 1,55 \\
\hline $\begin{array}{l}\mathrm{Ca}(\%) \\
\mathrm{Ca}(\%)\end{array}$ & 0,44 \\
\hline $\begin{array}{l}\mathrm{P}(\%) \\
P(\%)\end{array}$ & 0,26 \\
\hline $\begin{array}{l}{ }^{1} \text { Composição por } \mathrm{kg} \text { de mistura mineral: } \\
3.000 \mathrm{mg} \mathrm{Zn} ; 1.000 \mathrm{mg} \mathrm{Cu} ; 1.250 \mathrm{mg} \mathrm{Mn} ; 2.0 \\
\mathrm{~F} \text { (máximo). } \\
\text { Composition per } \mathrm{kg} \text { of mineral mixture: } \\
3,000 \mathrm{mg} \mathrm{Zn} \text {; 1,000mg Cu; } 1,250 \mathrm{mg} \mathrm{Mn;2,0} \\
F \text { (maximum). } \\
{ }^{2} \text { Estimado segundo } \mathrm{NRC}(1989) \text {. } \\
\text { Estimated by NRC (1989). }\end{array}$ & $\begin{array}{l}\mathrm{Mg} ; 20 \mathrm{~g} \mathrm{~S} ; 100 \mathrm{~g} \mathrm{Na} \text {; } \\
\mathrm{ng} \mathrm{I} ; 36 \mathrm{mg} \mathrm{Se} ; 900 \mathrm{mg} \\
\mathrm{Mg} ; 20 \mathrm{~g} \mathrm{~S} ; 100 \mathrm{~g} \mathrm{Na} \\
\mathrm{mg} \text { I; } 36 \mathrm{mg} \mathrm{Se} ; 900 \mathrm{mg}\end{array}$ \\
\hline
\end{tabular}


O período experimental foi de 21 dias. Os primeiros 16 dias foram destinados à adaptação dos animais às dietas, do $17^{\circ}$ ao $21^{\circ}$ para avaliação do consumo de MS e o $21^{\circ}$ para a colheita de líquido ruminal. Amostras de líquido ruminal foram colhidas às $0,2,4,6,8,10$ e 12 horas após a primeira refeição, em três pontos diferentes do rúmen, através de uma bomba de vácuo. Foram colhidos $500 \mathrm{~mL}$ de líquido ruminal dos quais $50 \mathrm{~mL}$ foram centrifugados a $2000 \mathrm{x}$ g por 15 minutos. $\mathrm{O}$ volume de $0,1 \mathrm{~mL}$ do sobrenadante foi colocado em tubo de ensaio e acrescido de $0,2 \mathrm{~mL}$ de ácido fórmico P.A. e congelado para posterior determinação dos AGVs. Após isso, $2 \mathrm{~mL}$ de líquido ruminal foram adicionados a $1 \mathrm{~mL}$ de solução de ácido sulfúrico (1 Normal) e congelados a $-20^{\circ} \mathrm{C}$ para posterior determinação do nitrogênio amoniacal $\left(\mathrm{N}^{-\mathrm{NH}_{3}}\right)$. Os AGVs foram determinados por cromatografia gasosa (ERWIN; MARCO; EMERY, 1961) em cromatógrafo a gás (marca FINNIGAN modelo 9001), equipado com coluna de sílica MEGABOR (marca OHIO VALLEY, modelo OV-351) de 30m x $0,53 \mathrm{~mm}$ e fase estacionária de 1,0 mícron. As análises de $\mathrm{N}-\mathrm{NH}_{3}$ foram realizadas por colorimetria, segundo método proposto por Kulasek (1972) e adaptado por Foldager (1977). O pH do fluído ruminal foi determinado utilizando potenciômetro digital portátil, calibrado com soluções tampão de pH 4,0 e 7,0.

As análises bromatológicas de MS, PB, EE, FB, MM, Ca e P da dieta foram realizadas segundo AOAC (1980) e de FDN e FDA segundo Van Soest, Robertson e Lewis (1991). Para a análise de FDN foi omitido o sulfito de sódio, mas adicionada a $\alpha$-amilase.

Os resultados foram analisados através do programa computacional Statistical Analysis System (SAS, 1985). Os dados de consumo de matéria seca 
foram submetidos à análise de variância (PROC GLM do SAS), que separou como única causa de variação o efeito de tratamento. Os dados referentes aos $\mathrm{AGVs}$, pH e concentrações de nitrogênio amoniacal no líquido ruminal foram analisados conforme descrito, porém adicionados do fator medidas repetidas no tempo (comando REPEATED do GLM do SAS), referentes aos diversos momentos de colheita entre as refeições. Na presença de interação entre tempo e tratamento, a análise de variância dentro de cada tempo foi realizada através do comando SLICE (GLM do SAS). A separação dos efeitos de tratamentos foi realizada através do teste Duncan, adotando-se o nível de significância de 5\%, exceto quando especificado.

\section{RESULTADOS E DISCUSSÃO}

Os dados de consumo de matéria seca encontram-se na Tabela 2. De forma geral, o consumo de matéria seca, que em média foi de $1,37 \%$ do peso vivo, independente do tratamento, apresentou-se um pouco abaixo do esperado, considerando-se esta categoria animal. Isto pode ter ocorrido em função da baixa qualidade da fibra da cana-de-açúcar, da alta condição corporal dos animais ao início do experimento ou a ambos os fatores. 
Tabela 2 - Consumo de matéria seca obtido com os tratamentos ${ }^{1}$

Table 2 - Dry matter intake obtained with treatments

\begin{tabular}{|c|c|c|c|c|c|c|}
\hline & \multicolumn{3}{|c|}{$\begin{array}{c}\text { Tratamentos }^{2} \\
\text { Treatments }\end{array}$} & \multirow[b]{2}{*}{$\begin{array}{l}\text { Média } \\
\text { Mean }\end{array}$} & \multirow[b]{2}{*}{$\begin{array}{l}\mathrm{CV} \\
\mathrm{CV}\end{array}$} & \multirow[b]{2}{*}{$\begin{array}{l}\text { Prob. } \\
\text { Prob. }\end{array}$} \\
\hline & $\begin{array}{c}\text { Controle } \\
\text { Control }\end{array}$ & $\begin{array}{l}\text { Flavomicina } \\
\text { Flavomycin }\end{array}$ & $\begin{array}{c}\text { Monensina } \\
\text { Monensin }\end{array}$ & & & \\
\hline $\begin{array}{l}\text { CMS } \\
D M I\end{array}$ & 10,56 & 8,93 & 11,33 & 10,27 & 19,24 & NS \\
\hline $\begin{array}{l}\mathrm{CMS} / \mathrm{PV} \\
D M I / B W\end{array}$ & 1,37 & 1,25 & 1,50 & 1,37 & 16,09 & NS \\
\hline $\begin{array}{l}\mathrm{CMS} / \mathrm{PV}^{0,75} \\
D M I / B W^{0,75}\end{array}$ & 72,13 & 64,55 & 78,71 & 71,80 & 16,43 & NS \\
\hline
\end{tabular}

${ }^{1} \mathrm{CMS}$ : consumo de matéria seca (kg/animal/dia), CMS/PV: consumo de matéria seca em função do peso vivo (\%), $\mathrm{CMS} / \mathrm{PV}^{0,75}$ : consumo de matéria seca em gramas por $\mathrm{kg}$ de peso vivo metabólico $(\mathrm{g} / \mathrm{kg}$ de $\left.\mathrm{PV}^{0,75}\right), \mathrm{CV}$ : coeficiente de variação (\%), Prob: probabilidades estatísticas, NS: não significativo.

DMI: dry matter intake (kg/animal/day), DMI/BW: dry matter intake per body weight (\%), DMI/BW $W^{0,75}$ : dry matter intake per $\mathrm{kg}$ of metabolic body weight $\left(\mathrm{g} / \mathrm{kg}\right.$ of $\left.B W^{0,75}\right), \mathrm{CV}$ : coefficient of variation (\%); Prob: statistical probability; NS: non-significant.

${ }^{2}$ Linhas com letras sobrescritas diferentes diferem pelo teste Duncan (5\%).

Rows with different letters differ by Duncan test (5\%).

No presente estudo, nenhum dos antibióticos testados alterou o consumo de matéria seca, fossem os dados expressos em quilos/animal/dia, em porcentagem do peso vivo ou em $\mathrm{g} / \mathrm{kg}$ de peso metabólico/dia. Esses resultados corroboram com Flachowsky e Richter (1991) que, realizando a adição de flavomicina (0 ou $30 \mathrm{~g} / \mathrm{animal} / \mathrm{dia}$ ) em novilhas, não observaram efeitos sobre o consumo de matéria seca, assim como Zinn, Plascencia e Barajas (1994), quando adicionaram monensina a dietas de novilhos contendo $10 \%$ ou $20 \%$ de volumosos, e Rodrigues, Lucci e Castro (2000), quando utilizaram diferentes proporções de volumoso:concentrado para testar os efeitos da lasalocida.

No entanto, em experimento realizado por Alert, Poppe e Lohner (1993), a adição de 50mg/animal/dia de flavomicina na dieta de touros confinados, resultou em 
maior consumo no grupo tratado quando comparado ao grupo controle. Porém, segundo Stock e Mader (1984), quando uma dieta rica em grãos é utilizada, os ionóforos geralmente deprimem o consumo de alimento, melhoram a conversão alimentar, aumentam ou mantém o ganho diário. Isto concorda, portanto, com Schelling (1984), que afirmou que a diminuição no consumo é mais evidente em animais alimentados com dieta rica em grãos do que com dieta volumosa, sob condições de confinamento.

Os dados de fermentação ruminal obtidos com os antibióticos encontram-se na Tabela 3. Tempo e tratamento interagiram para as variáveis $\mathrm{pH}(\mathrm{P}=0,0219)$ (Figura 1), concentração total de ácidos graxos voláteis $(\mathrm{P}=0,0425)$ (Figura 2), proporção molar de ácido acético $(\mathrm{P}=0,0246)$ (Figura 3), propiônico $(\mathrm{P}=0,0155)$ (Figura 4) e relação acético:propiônico ( $\mathrm{P}=0,0170)$ (Figura 5). 
Tabela 3 - Padrão de fermentação ruminal obtido com os tratamentos ${ }^{1}$ Table 3 - Ruminal fermentation pattern obtained with treatments

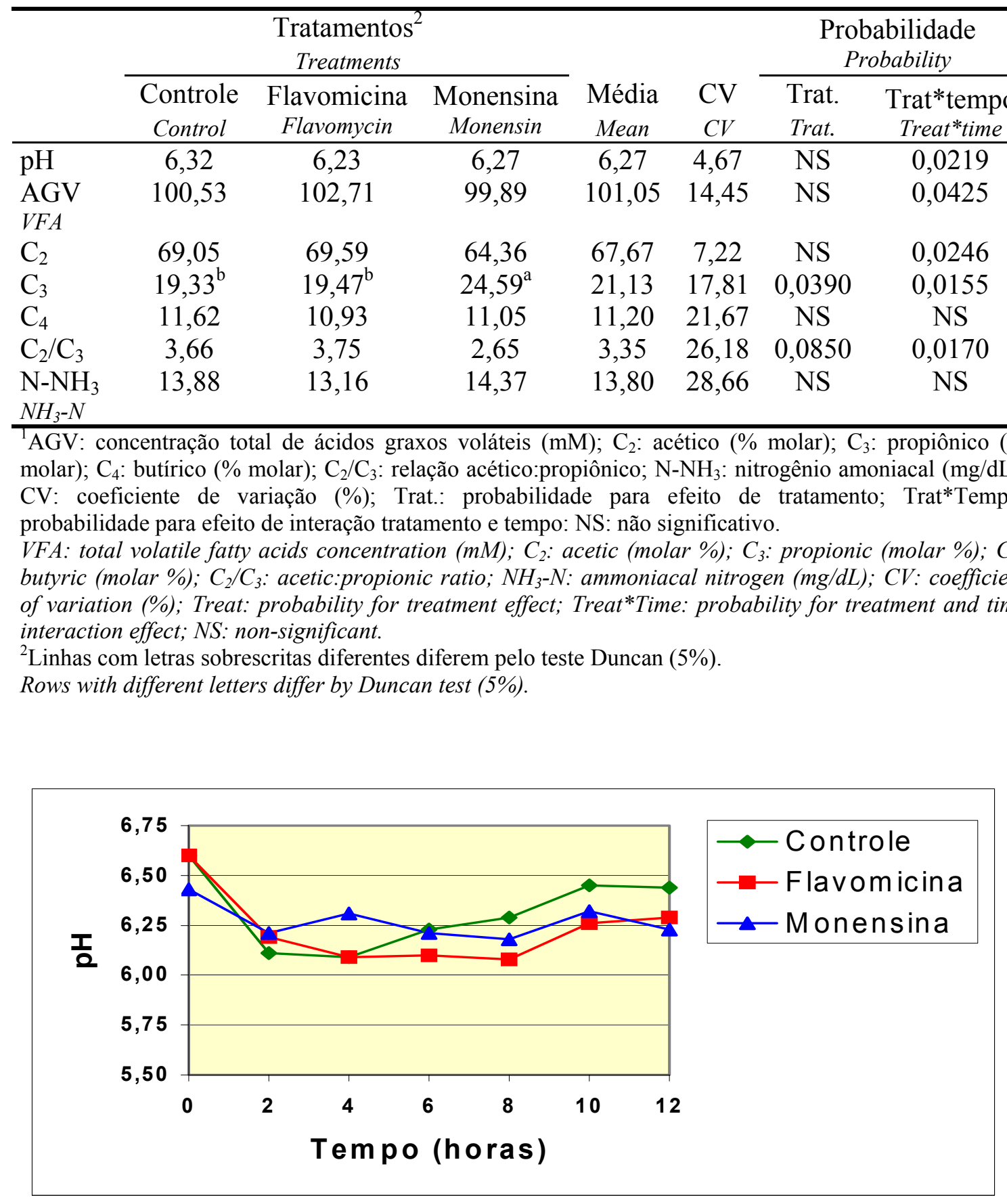

Figura $1-\mathrm{pH}$ do líquido ruminal Figure 1-Ruminal fluid $\mathrm{pH}$ 


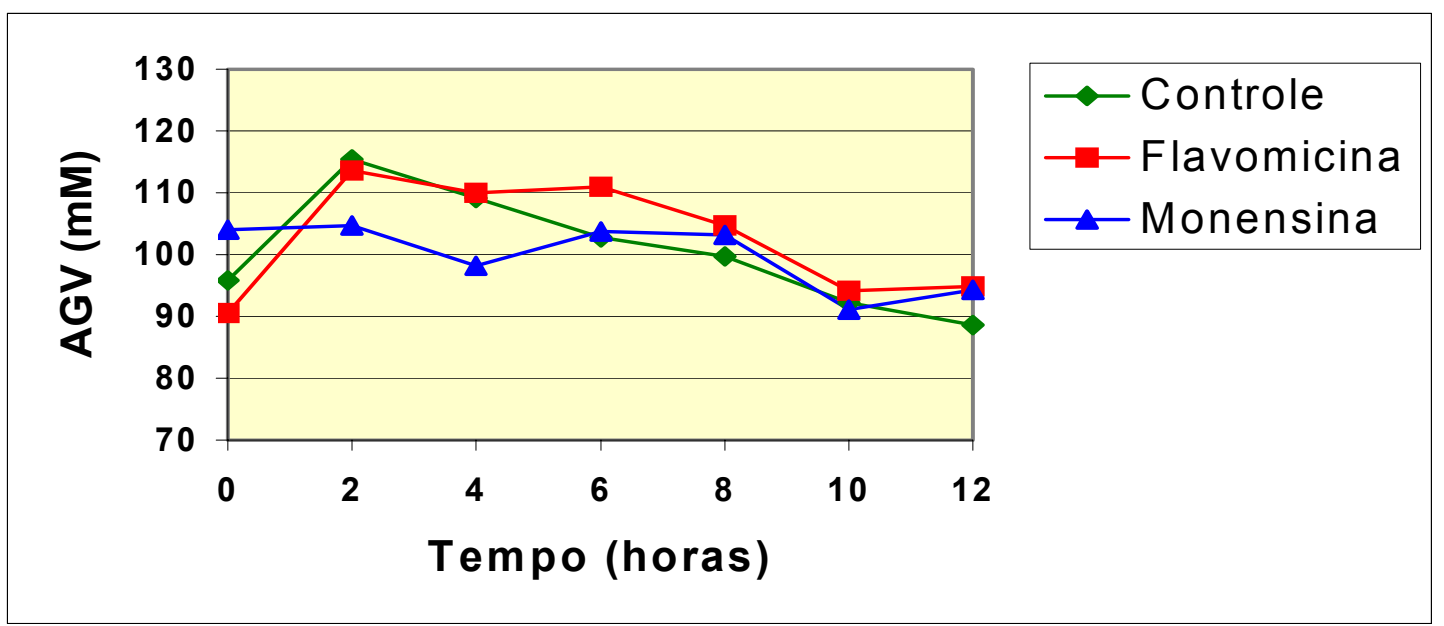

Figura 2 - Concentração total de AGVs (mM) no líquido ruminal Figure 2-Total VFA concentration (mM) in ruminal fluid

Embora tempo e tratamento tivessem interagido para as variáveis $\mathrm{pH}$ e concentração total de ácidos graxos voláteis, não foi constatado efeito de tratamento quando a análise foi realizada dentro de cada tempo. Estes achados estão de acordo com Rodrigues, Lucci e Castro (2000) que, ao estudarem os efeitos da lasalocida sobre a fermentação ruminal em vacas secas, verificaram que este ionóforo não causou alteração no pH ruminal e também não alterou a concentração total de AGVs. Do mesmo modo, Rodrigues et al. (2004) não observaram nenhum efeito na concentração total dos AGVs, quando estudaram os efeitos do nível de monensina sobre a fermentação ruminal em bovinos. Já Edwards et al. (2005), adicionando $20 \mathrm{mg} / \mathrm{kg} /$ dia de flavomicina à dieta mista de volumoso/concentrado para ovinos, observaram que as concentrações totais dos AGVs (acético, butírico, propiônico, valérico e isobutírico) diminuíram significativamente, como observaram outros autores (ALERT; POPPE; LOHNER, 1993; MAROUNEK; DUŠKOVÁ; SKŘIVANOVÁ, 1998; MCKAIN et al., 2000). Porém, não observaram nenhuma mudança significativa no $\mathrm{pH}$ ruminal. 
Outros pesquisadores como Mbanzamihigo, Van Nevel e Demeyer (1995), estudando a infusão de monensina no rúmen de carneiros fistulados, também observaram diminuição nas concentrações totais de ácidos graxos voláteis, porém o $\mathrm{pH}$ aumentou. Em parte, estes dados concordam com Murray, Rowe e Aitchison (1990) que, ao compararem o efeito da flavomicina utilizando duas dietas diferentes, verificaram que na dieta que continha alfafa/tremoço, o pH ruminal aumentou. A concentração total dos AGVs também aumentou, porém quando este tratamento foi comparado à dieta à base de trigo/farinha de peixe. Ainda em relação ao pH, Rodrigues et al. (2004), estudando os efeitos da monensina e diferentes proporções de volumoso/concentrado sobre a fermentação ruminal de bovinos, verificaram o aumento deste, porém somente na dieta mais concentrada. Estes dados se opõem aos de Zinn, Plascencia e Barajas (1994) os quais observaram que, aumentando o nível de volumoso na dieta, aumentou o $\mathrm{pH}$ ruminal.

Ao se avaliar os efeitos de tratamentos dentro de cada tempo, quando da presença de interação, observou-se que somente a monensina diminuiu significativamente a proporção molar de ácido acético, no tempo 0 hora (Figura 3). 


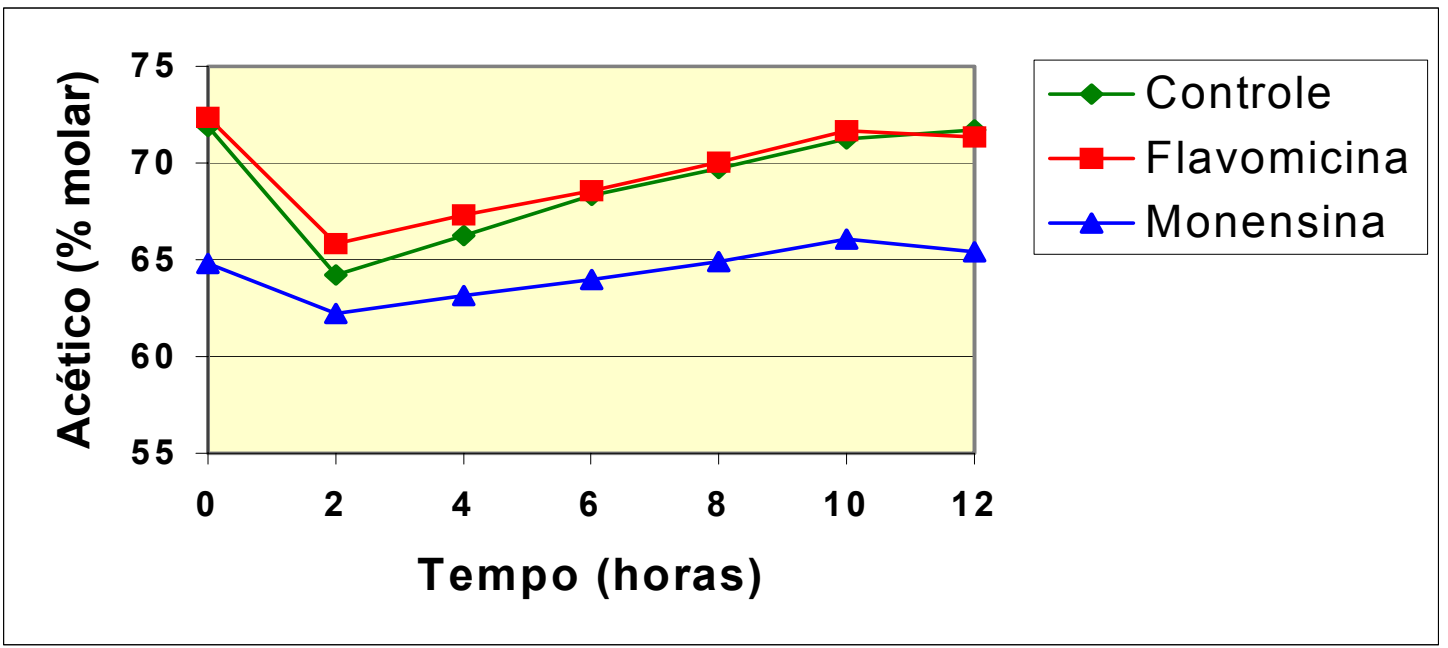

Figura 3 - Proporção molar de ácido acético no líquido ruminal Figure 3 - Molar percentage of acetic acid in ruminal fluid

Isto discorda, portanto, de Zinn, Plascencia e Barajas (1994), os quais ao analisarem o efeito de interação da monensina sobre a proporção de volumoso na dieta, observaram que o aumento de volumoso na dieta aumentou a proporção molar de acetato, e diminuiu a proporção molar de propionato. Murray, Rowe e Aitchison (1990), que observaram que a administração de flavomicina na dieta que continha trigo/farinha de peixe, aumentou a proporção molar de acetato e diminuiu a de propionato, mas não na dieta contendo alfafa/tremoço. Porém, Marounek, Dušková e Skřivanová (1998), ao testarem o efeito do antibiótico não-ionóforo flavomicina, verificaram que a proporção molar de acetato foi a mesma do grupo controle. Estes dados corroboram estudos anteriores sobre o efeito dos antibióticos não-ionóforos na fermentação ruminal ( $\mathrm{CHON}$ et al., 1989; FÉBEL et al., 1988; RUSSELL; STROBEL, 1988; VAN NEVEL; DEMEYER; HENDERICKX, 1984). 
Em relação ao ácido propiônico, a monensina aumentou sua proporção molar nos tempos $0,4,6,8,10$ e 12 horas, independente do tempo de amostragem, em relação ao grupo controle (Figura 4).

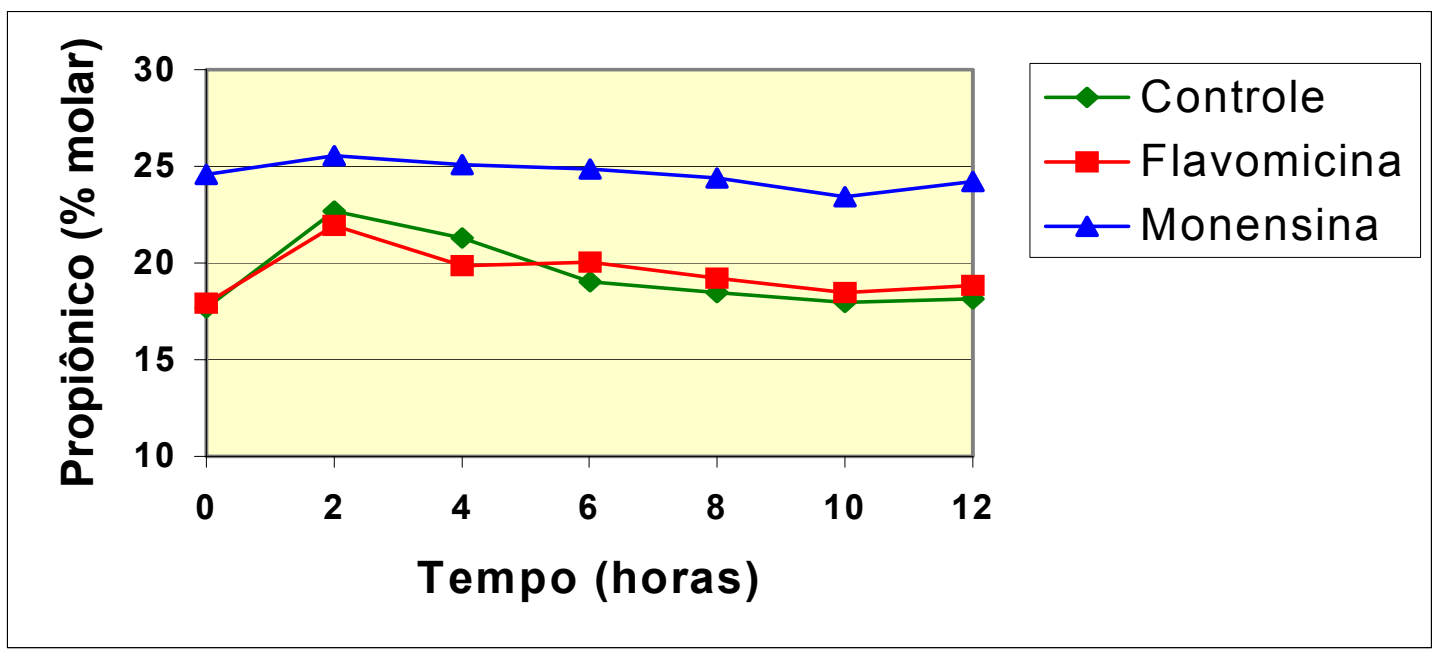

Figura 4 - Proporção molar de ácido propiônico no líquido ruminal Figure 4-Molar percentage of propionic acid in ruminal fluid

De forma geral, a monensina sódica aumentou a proporção molar de ácido propiônico em 27,2\% (5,26 unidades percentuais) em relação ao grupo controle, considerando todo o tempo de amostragem. Já a flavomicina não alterou esta variável em relação ao grupo controle.

Este relato está de acordo com experimento realizado por Ramanzin et al. (1997) que, ao alimentarem vacas leiteiras submetidas a dietas com $50 \%$ ou $30 \%$ de concentrado, observaram maiores efeitos da monensina sobre a proporção molar de propionato, sendo este efeito mais pronunciado na dieta mais concentrada $(26,7 \%$ x $8,9 \%$, respectivamente). Também Richardson et al. (1976), em experimento in vitro onde foram utilizados inóculos de animais alimentados com dieta rica em grãos, verificaram que diferentes concentrações de monensina aumentaram a produção de propionato e diminuíram a 
produção dos demais AGVs (acetato, butirato, valerato e isovalerato). Garcia-Lopez, Kung e Odom (1996), utilizando porcentagens diferentes de concentrados $(0 \%, 50 \%$ e 90\%) em experimento in vitro, notaram que a monensina aumentou a concentração de propionato em $17,1 \%$ e $47,9 \%$ para as dietas contendo $0 \%$ e $50 \%$ de concentrados, respectivamente, mas não alterou significativamente esta variável quando o meio continha $90 \%$ de concentrados. Estes últimos autores reconheceram a baixa dose utilizada como a causa da falta de efeito na dieta concentrada.

Quando a monensina foi administrada juntamente com silagem de milho e dieta concentrada, a taxa de produção de propionato aumentou em 65\% (ROGERS; DAVIS, 1982) e, quando administrada com trigo e dieta concentrada, o aumento foi de $44 \%$ (PRANGE; DAVIS; CLARK, 1978).

Segundo Chen e Wolin (1979), estes efeitos da monensina são decorrentes da ação inibitória sobre as bactérias produtoras de formato e hidrogênio e estimulatória sobre aquelas produtoras de succinato e propionato. Este fenômeno é duplamente vantajoso em termos metabólicos, já que a produção de propionato é energeticamente mais eficiente que a de acetato (CHALUPA, 1977; HUNGATE, 1966) e pelo fato de a utilização do propionato, nos tecidos, também ser mais eficiente que do acetato (SMITH, 1971).

Na figura 5, está ilustrada a relação acético:propiônico sob efeito dos antibióticos. A monensina diminuiu a relação acético:propiônico no tempo 0 hora, em relação ao grupo controle. No entanto, a flavomicina não mostrou qualquer alteração. Esta informação está de acordo com Alert, Poppe e Lohner (1993) que, ao avaliarem os efeitos da flavomicina no desempenho de touros em confinamento, observaram que a relação acético:propiônico não foi alterada. 


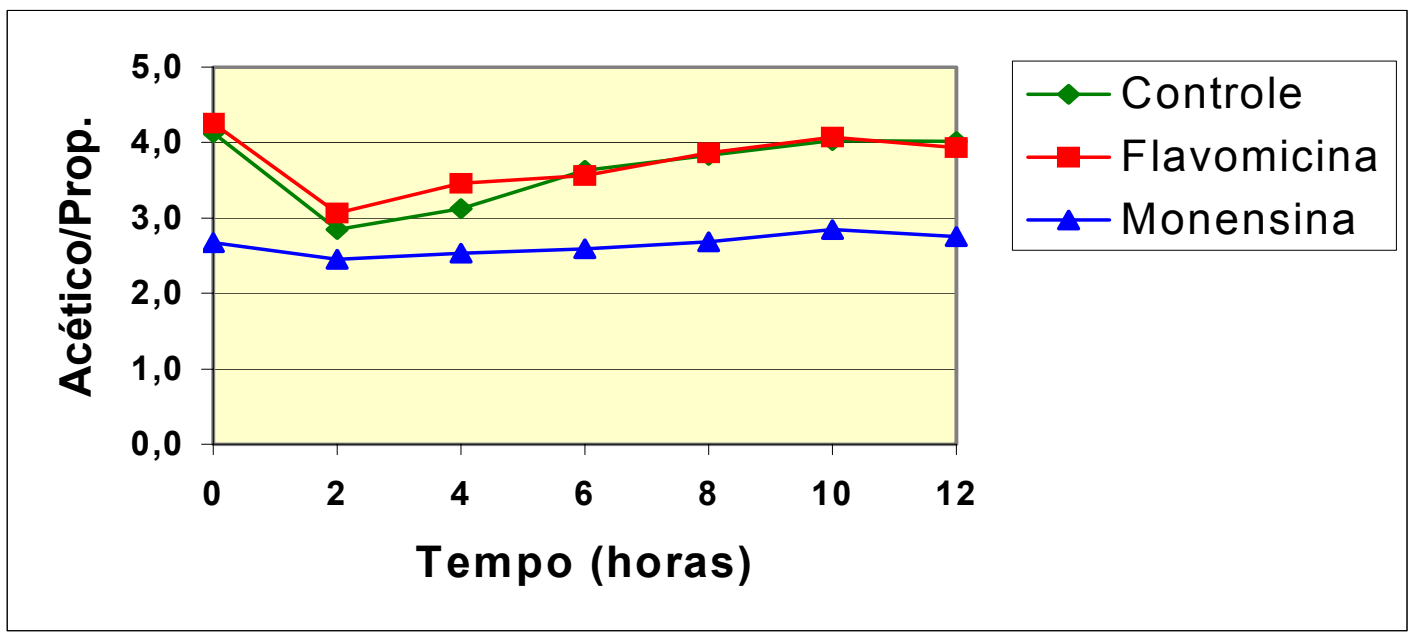

Figura 5 - Relação acético/propiônico no líquido ruminal Figure 5-Acetic:propionic ratio in ruminal fluid

Com relação à proporção molar de ácido butírico, os resultados do presente experimento estão de acordo com Zinn, Plascencia e Barajas (1994), quando avaliaram a interação do nível de forragem da dieta e administração de monensina. Também concordam com Rodrigues, Lucci e Castro (2000), quando estudaram o efeito da lasalocida e a proporção de volumoso/concentrado sobre a fermentação ruminal.

A flavomicina ou a monensina, nas doses utilizadas neste experimento, não causaram respostas em relação à concentração ruminal de nitrogênio amoniacal (Figura 6). Os dados do presente experimento discordam de Murray, Rowe e Aitchison (1990) que, em experimento com ovinos, relataram que a flavomicina diminuiu as concentrações ruminais de amônia somente na dieta que continha trigo/farinha de peixe. Salles e Lucci (2000), ao administrarem monensina para bezerros ruminantes em crescimento acelerado, observaram diminuição na concentração ruminal de nitrogênio amoniacal conforme aumentavam os níveis de monensina na dieta. Similarmente, Rodrigues et al. (2004), ao 
estudarem os efeitos da monensina em diferentes proporções volumoso/concentrado, observaram que este ionóforo diminuiu as concentrações ruminais de nitrogênio amoniacal, independente do nível de concentrado na dieta.

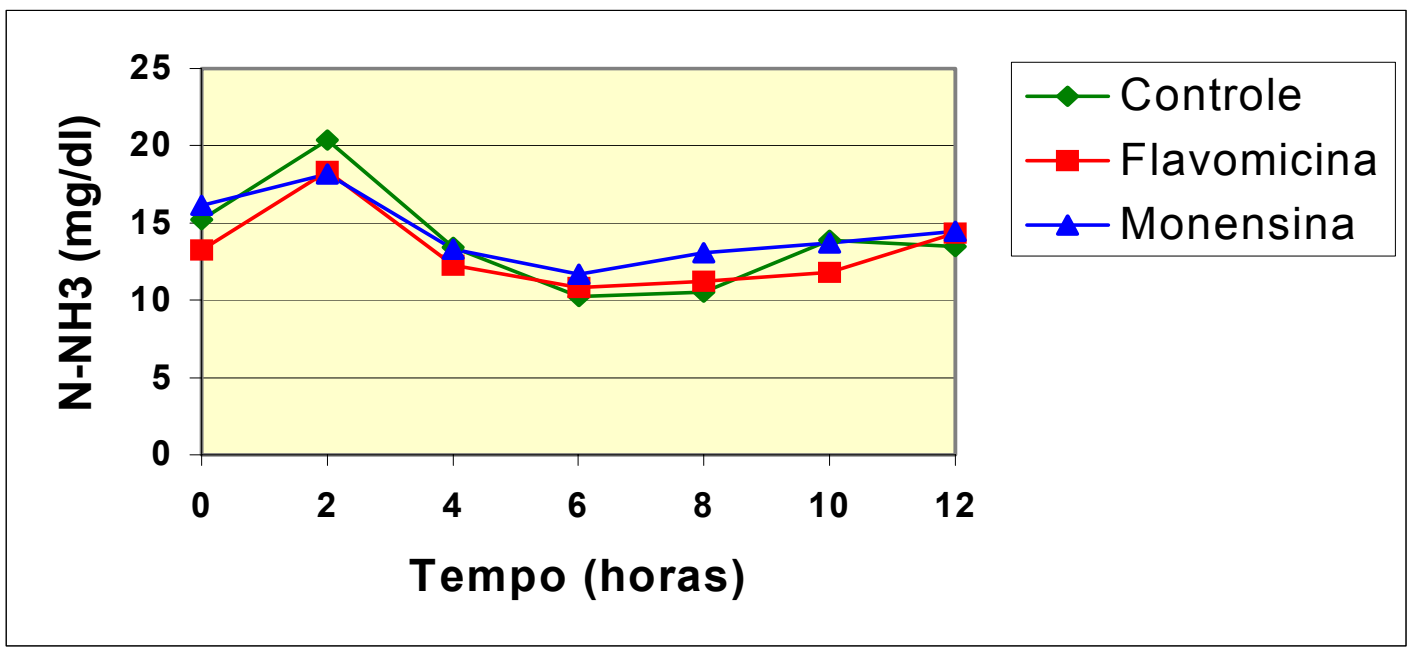

Figura 6 - Concentração de nitrogênio amoniacal $(\mathrm{mg} / \mathrm{dL})$ no líquido ruminal Figure 6 - Ammoniacal nitrogen concentration ( $\mathrm{mg} / \mathrm{dl}$ ) in ruminal fluid

Também Edwards, Wallace e McEwan (2002), estudando o modo de ação da flavomicina na dieta de ovinos recebendo trigo e concentrado, verificaram que houve diminuição de 14\% na concentração ruminal de nitrogênio amoniacal. Do mesmo modo, Edwards et al. (2005), ao realizarem experimento para observar a ação da flavomicina sobre a fermentação ruminal e sobre a população microbiana do rúmen, observaram que a suplementação deste não-ionóforo causou diminuição significativa nas concentrações ruminais de amônia, talvez devido à capacidade da flavomicina em restringir a conversão de aminoácidos em amônia, através da supressão direta de algumas bactérias AAPA (alta atividade de produção de amônia) ruminais. A diminuição ruminal na concentração da amônia pode ser indicativo do aumento da síntese de proteína bacteriana ou diminuição 
da deaminação (VAN DER MERWE; DUGMORE; WALSH, 2001). Entretanto, Rodrigues, Lucci e Castro (2000) não observaram qualquer efeito da lasalocida sobre as concentrações ruminais deste composto.

Segundo Russell, Strobel e Chen (1988) e Chen e Russell (1989), a redução da produção de amônia causada pela flavomicina, fato este não observado no presente experimento, é devida à inibição da pequena população de bactérias Gram positivas que realizam alta produção de amônia. Porém, quando o uso do antibiótico é suspenso, os efeitos não são prolongados. Estes dados foram confirmados por Lana et al. (2002) que, ao estudarem os efeitos de ionóforos em experimento in vitro, verificaram que houve aumento na produção de amônia quando a monensina foi removida do meio de cultura. 


\section{CONCLUSÃO}

Em condições de dietas predominantemente concentradas, com cana-deaçúcar como único volumoso, foi possível demonstrar os efeitos benéficos da monensina, mas não da flavomicina, sobre a fermentação ruminal. 


\section{RESUMO}

O objetivo do presente estudo foi caracterizar os efeitos da administração da flavomicina, em comparação com a monensina sódica, sobre a fermentação ruminal em bovinos. Doze fêmeas bovinas não-gestantes e não-lactantes (736 kg de PV) foram distribuídas inteiramente ao acaso aos três tratamentos formados por um grupo controle, um grupo tratado com flavomicina e outro tratado com monensina. A flavomicina foi administrada na dose de $20 \mathrm{mg} / \mathrm{animal} /$ dia e a monensina na dose de 300mg/animal/dia. O experimento teve duração total de 21 dias, sendo o $21^{\circ}$ dia utilizado para colheitas de líquido ruminal realizadas às $0,2,4,6,8,10$ e 12 horas após a primeira refeição. A monensina diminuiu a proporção molar de ácido acético a zero hora e aumentou a proporção molar de ácido propiônico nos tempos $0,4,6,8$, 10 e 12 horas após a alimentação, em relação ao grupo controle e à flavomicina. $\mathrm{O}$ aumento médio sobre a proporção molar de ácido propiônico causado pela monensina foi de $27,2 \%$ em relação ao grupo controle. Nenhum dos antibióticos testados alterou a concentração total de AGVs ou a proporção molar de ácido butírico, bem como o pH ou a concentração ruminal de nitrogênio amoniacal. Também não alteraram o consumo de matéria seca.

Palavras-chave: Ácidos graxos voláteis. Consumo. Ionóforo. Antibiótico nãoionóforo. Ruminantes. 


\section{ABSTRACT}

The aim of the present study was to characterize the effects of the addition of flavomycin or monensin on ruminal fermentation in bovine. Twelve non-pregnant and non-lactating cows (736 kg of BW) were randomly assigned to three treatments: control group, flavomycin-treated group and monensin-treated group. Treatments were $20 \mathrm{mg} / \mathrm{animal} /$ day of flavomycin or $300 \mathrm{mg} / \mathrm{animal} /$ day of monensin. Trial lasted 21 days. The $21^{\text {st }}$ day was used for ruminal fluid sampling at $0,2,4,6,8,10$ and 12 hours after the first meal. Monensin decreased the molar proportion of acetic acid at time 0 and increased the propionic acid at times $0,4,6,8,10$ and 12 hours after feeding, compared to control and flavomycin groups. The average increase in propionic acid molar proportion due to monensin addition was $27.2 \%$ when compared to control group. Total VFAs concentrations, molar proportion of butyric acid, $\mathrm{pH}$, ammoniacal-N concentration or dry matter intake were not influenced by the addition of either antibiotics.

Key words: Intake. Ionophore. Non-Ionophore antibiotic. Ruminants. Volatile fatty acids. 


\section{REFERÊNCIAS}

ALERT, H. J.; POPPE, S.; LOHNER, M. The effect of flavomycin on the fattening performance of bulls. Arch Tierernahr, v. 43, n. 4, p. 371-380, 1993.

AOAC - ASSOCIATION OF OFFICIAL ANALYTICAL CHEMISTS. 1980. Official methods of analysis. 10. ed. Washington, D.C.: Association of Analytical Chemistry. 1015p.

CHALUPA, W. Manipulating the rumen fermentation. Journal of Animal Science, v. 45, n. 3, p. 585-599, 1977.

CHEN, G.; RUSSELL, J. B. Effect of monensin and protonophore on protein degradation, peptide accumulation and deamination by mixed ruminal microorganisms in vitro. Journal of Animal Science, v. 69, n. 5, p. 2196-2203, 1991.

CHEN, G.; RUSSELL, J. B. More monensin-sensitive, ammonia-producing bacteria from the rumen. Applied and Environmental Microbiology, v. 55, n. 5, p. 10521057, 1989.

CHEN, M.; WOLIN, M. J. Effect of monensin and lasalocid-sodium on the growth of methanogenic and rumen saccharolytic bacteria. Applied and Environmental Microbiology, v. 38, p. 72-77, 1979.

CHON, S. B.; SAVKA, O. G.; BŘEZINA, P.; MAROUNEK, M. Effect of tylosin on rumen fermentation in vitro. Acta Veterinaria Brunensis, v. 58, p. 313-321, 1989.

DENNIS, S. M.; NAGARAJA, T. G.; BARTLEY, E. E. Effects of lasolacid or monensin on lactate producing or using rumen bacteria. Journal of Animal Science, v. 52, n. 2, p. 418-426, 1981.

DUFFIELD, T. F.; SANDALS, D.; LESLIE, K. E.; LISSEMORE, K.; MCBRIDE, B. W.; LUMSDEN, J. H.; DICK, P.; BAGG, R. Effect of prepartum administration of monensin in a controlled-release capsule on postpartum energy indicators in lactating dairy cows. Journal of Dairy science, v. 81, n. 9, p. 2354-2361, 1998.

EDWARDS, J. E.; MCEWAN, N. R.; MCKAIN, N.; WALKER, N.; WALLACE, R. $\mathrm{J}$. Influence of flavomycin on ruminal fermentation and microbial populations in sheep. Microbiology, v. 151, n. 3, p. 717-725, 2005. 
EDWARDS, J. E.; WALLACE, R. J.; MCEWAN, N. R. The growth promoting mode of action of flavomycin in ruminants. Reproduction Nutrition Development, v. 42, p. (S)55-56, 2002. Sessão V (O-23).

ERWIN, E. S.; MARCO, G. J.; EMERY, E. M. Volatile fatty acid analyses of blood and rumen fluid by gas chromatography. Journal of Dairy Science, v. 44, n. 9, p. 1768-1771, 1961.

FÉBEL, H.; SZELÉNYI, M.; JÉCSAI, J.; JUHÁSZ, B. Effect of salinomycin, flavomycin and avoparcin on some physiological traits of growing lambs, with particular respect to rumen fermentation. Acta Veterinaria Hungarica, v. 36, n. 1-2, p. 69-80, 1988.

FLACHOWSKY, G.; RICHTER, G. H. Effect of flavomycin on the apparent digestibility of crude nutrients in wethers, parameters of rumen fermentation in cattle and feed intake and weight gain of heifers. Arch Tierernahr, v. 41, n. 3, p. 303-310, 1991.

FOLDAGER, J. Protein requirement and non-protein nitrogen for high producing cow in early lactation. 1977. 167p. Tese (Doutorado em Ciência Animal) - Michigan State University, East Lasing, 1977.

FUNK, M. A.; GALYEAN, M. L.; ROSS, T. T. Potassium and lasalocid effects on performance and digestion in lambs. Journal of Animal Science, v. 63, n. 3, p. 685 $691,1986$.

GARCIA-LOPEZ, P. M.; KUNG, L.; ODOM, J. M. In vitro inhibition of microbial methane production by 9,10-Anthraquinone. Journal of Animal Science, v. 74, n. 9, p. 2276-2284, 1996.

HUNGATE, R. E. The Rumen and its Microbes. New York: Academic Press, 1966. p. 206.

KULASEK, G. A micromethod for determination of urea in plasma, whole blood and blood cells using urease and phenol reagent. Polskie Archiwum Medycyny Wewnetrznej, v. 15, n. 4, p. 801-810, 1972.

LANA, R. P.; OLIVEIRA, J. S.; BORGES, A. C.; VELOSO, R. G.; NUNES, P. M. M. Efeito da monensina e lasalocida sobre a atividade de fermentação de aminoácidos in vitro pelos microrganismos ruminais. Revista Brasileira de Zootecnia, v. 31, n. 2, p. 724-730, 2002.

MAROUNEK, M.; DUŠKOVÁ, D.; SKŘIVANOVÁ, V. Effect of non-ionophore feed antibiotics on in vitro fermentation in the ovine rumen and rabbit caecum. The Journal of Agricultural Science, v. 130, n. 1, p. 115-118, 1998. 
MBANZAMIHIGO L.; VAN NEVEL C. J.; DEMEYER D. I. Adaptation of rumen fermentation to monensin. Reproduction Nutrition Development, v. 35, n. 4, p. 353-365, 1995.

MCGUFFEY, R. K.; RICHARDSON, L. F. WILKINSON, J. I. D. Ionophores for dairy cattle: Current status and future outlook. Journal of Dairy Science, v. 84, p. 194-203, 2001. Suplemento E.

MCKAIN, N.; EDWARDS, J.; WALLACE, R. J.; EDWARDS, S.; BRUCE, L.; BEQUETTE, B. J.; MACRAE, J. C. Effects of flavomycin in the gastrointestinal tract of sheep. Reproduction Nutrition Development, v. 40, n. 2, p. 222, 2000. Sessão V.

MURRAY, P. J.; ROWE, J. B.; AITCHISON, E. M. The influence of protein quality on the effect of flavomycin on wool growth, liveweight change and rumen fermentation in sheep. Australian Journal of Agricultural Research, v. 41, p. 987993, 1990.

NAGARAJA, T. G.; NEWBOLD, C. J.; VAN NEVEL, C. J.; DEMEYER, D. I. Manipulation of ruminal fermentation. In:

2. ed., New York: Blackie, 1997. p. 523-632. . The rumen microbial ecosystem,

NRC - NATIONAL RESEARCH COUNCIL. Nutritional Requirements of Dairy Cattle, 6.ed., Washington D. C.: National Academy Press, 1989.

OVCHINNIKOV, Y. A. Physico-chemical basic of ion transport through biological membranes: Ionophores and ion channels. European Journal of Biochemistry, v. 94, n. 2, p. 321-336, 1979.

PARKER, D. S.; ARMSTRONG, D. G. Antibiotic feed additives and livestock production. Proceedings of the Nutritional Society, v. 46, n. 3, p. 415-421, 1987.

PHIPPS, R. H., WILKINSON, J. I. D.; JONKER, L. J.; TARRANT, D.; JONES, B. A.; HODGE, A. Effect of monensin on milk production of Holstein-Friesian dairy cows. Journal of Dairy Science, v. 83, n. 12, p. 2789-2794, 2000.

PRANGE, R. W.; DAVIS, C. L.; CLARK, J. H. Propionate production in the rumen of Holstein steers fed either a control or a monensin supplemented diet. Journal of Animal Science, v. 46, p. 1120-1124, 1978.

RAMANZIN, M.; BAILONI, L.; SCHIAVON, S.; BITTANTE, G. Effect of monensin on milk production and efficiency of dairy cows fed two diets differing in forage to concentrate ratios. Journal of Dairy Science, v. 80, n. 6, p. 1136-1142, 1997. 
RICHARDSON, L. F.; RAUN, A. P.; POTTER, E. L.; COOLEY, C. O. Effect of monensin in rumen fermentation in vitro and in vivo. Journal of Animal Science, v. 43, n. 3, p. 657-664, 1976.

RODRIGUES, P. H. M.; LUCCI, C. S.; CASTRO, A. L. Efeitos da lasalocida sódica e proporção volumoso/concentrados sobre a fermentação ruminal em vacas secas.

Brazilian Journal of Veterinary Research and Animal Science, v. 37, n. 3, p. 253 258, 2000.

RODRIGUES, P. H. M.; MATTOS, W. R. S.; MEYER, P. M.; LUCCI, C. S.; MELOTTI, L. Effects of monensin level and roughage/concentrate ratio on ruminal fermentation in bovines. Journal of Animal and Feed Sciences, v. 13, p. 195-198, 2004. Suplemento 1.

ROGERS, J. A.; DAVIS, C. L. Rumen volatile fatty acid production and nutrient utilization in steers fed a diet supplemented with sodium bicarbonate and monensin. Journal of Dairy Science, v. 65, n. 6, p. 944-952, 1982.

RUSSELL, J. B.; STROBEL, H. J. Effects of additives on in vitro ruminal fermentation: A comparison of monensin and bacitracin, another gram-positive antibiotic. Journal of Animal Science, v. 66, n. 2, p. 552-558, 1988.

RUSSELL, J. B.; STROBEL, H. J.; CHEN, G. Enrichment and isolation of a ruminal bacterium with a very high specific activity of ammonia production. Applied and Environmental Microbiology, v. 54, n. 4, p. 872-877, 1988.

SALLES, M. S. V.; LUCCI, C. S. Monensina para bezerros ruminantes em crescimento acelerado. 2. Digestibilidade e parâmetros ruminais. Revista Brasileira de Zootecnia, v. 29, n. 2, p. 582-588, 2000.

SAS - STATISTICAL ANALISYS SYSTEM. SAS user's guide: Statistics. Versão 5. Cary: SAS, 1985.

SCHELLING, G. T. Monensin mode of action in the rumen. Journal of Animal Science, v. 58, n. 6, p. 1518-1527, 1984.

SMITH, G. E. Energy metabolism, digestive physiology and nutrition of ruminants, Corvallis-OR: O and B Books, 1971.601p.

STOCK, R.; MADER, T. Feed additives for beef cattle. Feeding and Nutrition. Nebraska, NE, set.1984. Disponível em:

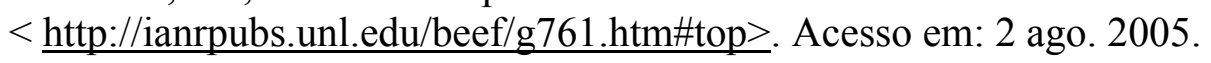

VAN DER MERWE, B. J.; DUGMORE, T. J.; WALSH, K. P. The effect of flavophospholipol $\left(\right.$ Flavomycin ${ }^{\circledR}$ ) on milk production and milk urea nitrogen 
concentrations of grazing dairy cows. South African Journal of Animal Science, v. 31, n. 2, p. 101-105, 2001.

VAN MAANEN, R. W.; HERBEIN, J. H.; MCGILLIARD, A. D.; YOUNG, J. W. Effects of monensin on in vivo rumen propionate production and blood glucose.

Journal of Nutrition, v. 108, n. 6, p. 1002-1007, 1978.

VAN NEVEL, C. J.; DEMEYER, D. I.; HENDERICKX, H. K. Effect of virginiamycin on carbohidrate and protein metabolism in the rumen in vitro. Archiv Für Tierenährung, v. 34, n. 2, p. 149-155, 1984.

VAN SOEST, P. J.; ROBERTSON, J. B.; LEWIS, B. A. Methods of dietary fiber, neutral detergent fiber, and non starch polysaccharides in relation to animal nutrition. Journal of Dairy Science, v. 74, n. 10, p. 3583-3597, 1991.

ZINN, R. A; PLASCENCIA, A.; BARAJAS, R. Interaction of forage level and monensin in diets for feedlot cattle on growth performance and digestive function. Journal of Animal Science, v. 72, n. 9, p. 2209-2215, 1994. 


\section{CAPÍTULO IV}

\section{EFEITOS DA FLAVOMICINA OU DA MONENSINA SOBRE A DIGESTÃO RUMINAL E TOTAL EM BOVINOS}

\section{INTRODUÇÃO}

Durante muito tempo, procurou-se manipular a fermentação ruminal, melhorando sua eficiência, seja através do aumento da produção do ácido propiônico, da diminuição da metanogênese ou da diminuição da proteólise e deaminação de proteínas no rúmen. Inicialmente este objetivo foi perseguido apenas através da manipulação da dieta. Entretanto, a descoberta de compostos químicos ativos no rúmen abriu grandes perspectivas nesta área das ciências agrícolas (BERGEN; BATES, 1984).

Os produtos mais utilizados hoje em dia para ruminantes são os ionóforos, tais como monensina, lasalocida, salinomicina e narasina, que são substâncias produzidas por várias cepas de Streptomyces sp. (OVCHINNIKOV, 1979). Em menor escala são utilizados alguns antibióticos não-ionóforos, como avoparcina, flavomicina, tilosina, virginamicina (MAROUNEK; DUŠKOVÁ; SKŘIVANOVÁ, 1998).

Os antibióticos ionóforos possuem a capacidade de aumentar a eficiência do metabolismo energético e protéico no rúmen e no animal, além de diminuírem a incidência de distúrbios digestivos (BERGEN; BATES, 1984). A ação destes antibióticos 
é de promover um ambiente competitivo em favor de alguns microrganismos às custas de outros. Em geral, há melhora do metabolismo energético, através do aumento da produção de propionato entre os ácidos graxos voláteis ruminais, e concomitante redução na produção de metano. Também é reduzida a degradação de peptídios e aminoácidos, aumentando, portanto, o fluxo de proteína de origem dietária para o intestino delgado.

O objetivo do presente experimento foi estudar os efeitos da administração da flavomicina, em comparação com a monensina sódica, sobre digestão ruminal e total dos nutrientes da dieta, bem como sobre o consumo de matéria seca digestível e de NDT, em bovinos. 


\section{MATERIAL E MÉTODOS}

O experimento foi conduzido nas dependências do Departamento de Nutrição e Produção Animal da Faculdade de Medicina Veterinária e Zootecnia da Universidade de São Paulo (Campus de Pirassununga).

Foram utilizadas doze fêmeas bovinas mestiças, portadoras de fístulas ruminais, que possuíam aproximadamente $736 \mathrm{~kg}$ de peso vivo ao início do experimento e apresentavam-se não-lactantes e não-gestantes. O estábulo utilizado possuía baias individuais, com cochos de cimento, bebedouros automáticos, piso emborrachado e ventiladores suspensos ao teto, que eram ligados nas horas mais quentes do dia. $\mathrm{O}$ delineamento experimental foi o inteiramente casualizado com três tratamentos, correspondendo ao controle negativo (ausência de antibiótico), tratado (flavomicina) e controle positivo (monensina sódica). Para o tratamento com flavomicina foi utilizada a dose de 20mg/animal/dia (250mg de produto comercial/animal/dia). Para o tratamento com monensina foi utilizado o produto comercial Rumensin ${ }^{\circledR}$ (Elanco), na dose de 300mg de monensina sódica/animal/dia. Cada produto foi pesado separadamente em balança analítica e depois acondicionado em envelopes confeccionados em papel absorvente. Estes foram administrados diariamente no interior do rúmen, através da fístula ruminal, durante o momento das refeições e misturados ao conteúdo ruminal por meio de agitação manual. Os animais foram alimentados duas vezes ao dia, às 8:00h e 16:00h, com uma dieta contendo $60 \%$ de concentrados e $40 \%$ de volumoso (Tabela 1 ). A dieta foi fornecida na forma de mistura completa, permitindo-se $10 \%$ de sobras. 
Tabela 1 - Proporções de ingredientes utilizados e composição bromatológica das rações, com base na matéria seca

Tabela 1 - Ingredients and chemical composition of diets (DM basis)

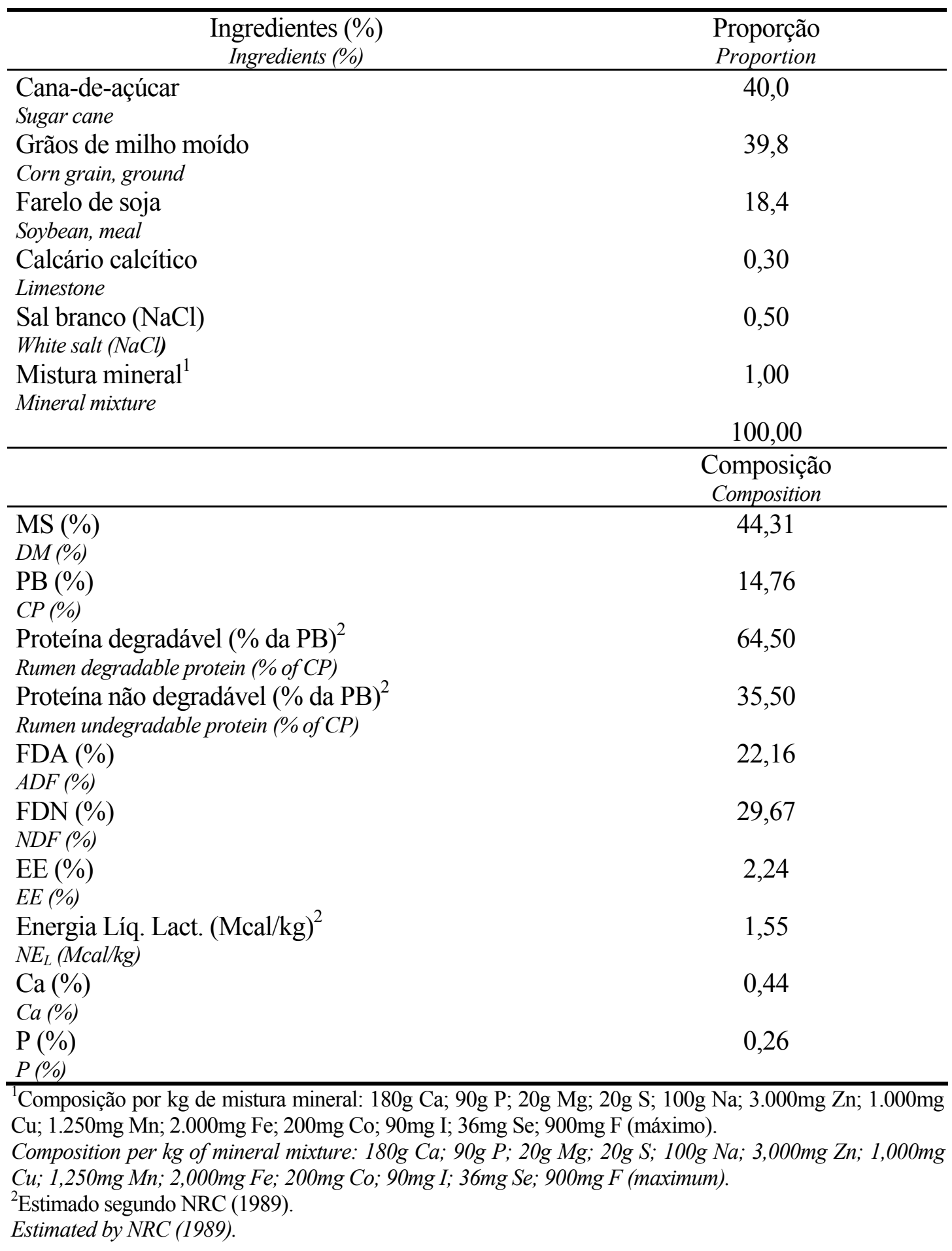


O período experimental constituiu-se de 21 dias, dos quais os primeiros 16 dias foram destinados à adaptação dos animais às dietas. Entre o $11^{\circ}$ e o $21^{\circ}$ dia foi feita avaliação da digestibilidade in vivo e entre o $17^{\circ}$ e o $21^{\circ}$ a avaliação da degradabilidade in situ.

As degradabilidades da FDN da cana-de-açúcar, do amido do milho em grãos e da proteína bruta do farelo de soja foram medidas através da técnica de sacos de nylon in situ (MEHREZ; ØRSKOV, 1977). Para tal, utilizaram-se sacos medindo 10,0 x 20,0 cm que abrigaram, separadamente, aproximadamente 6 gramas de cada alimento secado em estufa de circulação de ar forçado a $65^{\circ} \mathrm{C}$ por 72 horas, previamente moído em peneira de $5 \mathrm{~mm}$.

Os sacos foram incubados no rúmen durante $0 ; 6 ; 12 ; 24 ; 48 ; 72$ e 96 horas para a cana-de-açúcar, $0 ; 3 ; 6 ; 12 ; 24 ; 48$ e 72 horas para o milho em grãos e $0 ; 1,5 ; 3 ; 6 ; 12 ; 24$ e 48 horas para o farelo de soja. Após o período de incubação, os sacos eram imediatamente lavados em água corrente até que o líquido de lavagem fluísse incolor, sendo então colocados em estufa a $65^{\circ} \mathrm{C}$ por 72 horas para posteriormente serem pesados e submetidos a análises bromatológicas. A degradabilidade em tempo zero foi tomada mergulhando-se os sacos em um recipiente contendo água à temperatura de $39^{\circ} \mathrm{C}$ durante 10 minutos.

As análises bromatológicas dos alimentos incubados foram realizadas conforme descrito e os resultados de composição bromatológica de cada alimentos encontram-se na tabela 2 . 
Tabela 2 - Composição bromatológica dos alimentos ${ }^{1}$

Table 2 - Chemical composition of feeds

\begin{tabular}{|c|c|c|c|c|c|c|c|c|}
\hline $\begin{array}{l}\text { Alimento } \\
\text { Feed }\end{array}$ & $\begin{array}{l}\mathrm{PB} \\
C P\end{array}$ & $\begin{array}{l}\mathrm{EE} \\
E E\end{array}$ & $\begin{array}{l}\mathrm{MM} \\
\text { Ash }\end{array}$ & $\begin{array}{l}\text { FB } \\
C F\end{array}$ & $\begin{array}{l}\text { FDN } \\
N D F\end{array}$ & $\begin{array}{l}\text { Amido } \\
\text { Starch }\end{array}$ & $\begin{array}{l}\mathrm{Ca} \\
\mathrm{Ca}\end{array}$ & $\begin{array}{l}\mathrm{P} \\
P\end{array}$ \\
\hline $\begin{array}{l}\text { Cana } \\
\text { Sugar cane }\end{array}$ & 1,51 & 0,87 & 1,03 & 26,15 & 55,63 & 0,19 & 0,17 & 0,04 \\
\hline $\begin{array}{l}\text { Milho grão } \\
\text { Corn grain }\end{array}$ & 9,61 & 4,09 & 1,29 & 3,48 & 13,90 & 61,44 & 0,03 & 0,22 \\
\hline $\begin{array}{l}\text { Far. Soja } \\
\text { Soybean meal }\end{array}$ & 50,05 & 1,71 & 6,24 & 7,00 & 11,77 & 0,47 & 0,32 & 0,61 \\
\hline
\end{tabular}

Os dados de degradabilidade, calculados através da diferença de pesagens dos sacos antes e após a incubação, foram ajustados segundo a equação $p=a+b\left(1-e^{-c t}\right)$ (ØRSKOV; MCDONALD, 1979), onde $p$ é a quantidade degradada ao tempo $(t), a$ representa a fração rapidamente solúvel, $b$ é a fração potencialmente degradável e $c$ a taxa de degradação na qual a fração descrita por $b$ será degradada por hora. As constantes $a, b$ e $c$ da equação exponencial, foram utilizadas para calcular a degradabilidade potencial ( $a$ $+b)$ e a degradabilidade efetiva ( $D e$ ) calculada através da seguinte fórmula (AFRC, 1992): $D e=a+(b \times c) /(c+k)$, onde $k$ representa a taxa de saída do rúmen por hora, sendo utilizadas taxas iguais a $0,02 / \mathrm{h}, 0,05 / \mathrm{h}$ e $0,08 / \mathrm{h}$.

A digestibilidade da MS da dieta e suas frações (PB, EE, ENN, FB, FDN, FDA, amido e energia bruta) foram avaliadas através do marcador óxido crômico (BATEMAN, 1970). Os animais receberam o óxido crômico, via fístula ruminal, na dosagem de $15 \mathrm{~g}$ do marcador por animal e por dia, sendo as administrações realizadas duas vezes ao dia, no momento das refeições, e através de envelopes confeccionados em papel absorvente. $\mathrm{O}$ ensaio foi constituído de duas fases, compreendidas entre o $11^{\circ}$ e $21^{\circ}$ dia, sendo uma fase 
de administração do marcador e outra de administração do marcador e coleta de fezes, com duração de 5 dias cada uma, assegurando-se desta forma uma excreção homogênea do óxido crômico. Para comporem uma amostra final, alimentos e fezes foram amostrados duas vezes ao dia, próximos às refeições, sendo a de fezes realizada diretamente do reto.

A concentração do óxido crômico foi determinada por colorimetria através de sua reação com a s-difenilcarbazida, segundo Graner (1972). As análises bromatológicas de MS, PB, EE, FB e MM foram realizadas segundo AOAC (1980) e de FDN e FDA segundo Van Soest, Robertson e Lewis (1991). Para a análise de FDN foi omitido o sulfito de sódio, mas adicionada a $\alpha$-amilase. A concentração de amido foi avaliada segundo Pereira e Rossi (1995), modificando-se esta metodologia com a prévia extração dos carboidratos solúveis segundo Hendrix (1993).

Os resultados foram analisados através do programa computacional Statistical Analysis System (SAS, 1985) e submetidos à análise de variância (PROC GLM do SAS) e teste Duncan, para separar os efeitos de tratamentos. Adotou-se o nível de significância de $5 \%$, exceto quando especificado. 


\section{RESULTADOS E DISCUSSÃO}

Os dados de degradabilidade da FDN da cana-de-açúcar encontram-se na tabela 3.

Nenhum dos tratamentos testados alterou os parâmetros de degradabilidade ruminal da FDN da cana-de-açúcar.

Tabela 3 - Degradabilidade ruminal da FDN da cana-de-açúcar obtida com os tratamentos

Table 3 - Ruminal degradability of sugar cane NDF obtained with treatments

\begin{tabular}{|c|c|c|c|c|c|c|}
\hline & & $\begin{array}{c}\text { Tratamentos } \\
\text { Treatments }\end{array}$ & & & & \\
\hline & $\begin{array}{c}\text { Controle } \\
\text { Control }\end{array}$ & $\begin{array}{c}\text { Flavomicina } \\
\text { Flavomycin }\end{array}$ & $\begin{array}{c}\text { Monensina } \\
\text { Monensin }\end{array}$ & $\begin{array}{l}\text { Média } \\
\text { Mean }\end{array}$ & $\begin{array}{l}\mathrm{CV} \\
\mathrm{CV}\end{array}$ & $\begin{array}{l}\text { Prob. } \\
\text { Prob. }\end{array}$ \\
\hline$a$ & 7,59 & 7,56 & 8,55 & 7,90 & 13,23 & NS \\
\hline $\begin{array}{l}a \\
\mathrm{~b} \\
b\end{array}$ & 47,08 & 51,05 & 42,29 & 46,81 & 14,76 & NS \\
\hline $\begin{array}{l}\mathrm{c} \\
c\end{array}$ & 0,0245 & 0,0143 & 0,0183 & 0,0190 & 44,26 & NS \\
\hline $\begin{array}{l}\text { De2 } \\
E d 2\end{array}$ & 32,92 & 28,24 & 27,50 & 29,56 & 20,01 & NS \\
\hline $\begin{array}{l}\text { De5 } \\
E d 5\end{array}$ & 22,69 & 18,83 & 19,30 & 20,27 & 20,06 & NS \\
\hline $\begin{array}{l}\text { De8 } \\
E d 8\end{array}$ & 18,36 & 15,33 & 16,08 & 16,59 & 18,43 & NS \\
\hline $\begin{array}{l}\mathrm{Dp} \\
P d\end{array}$ & 54,66 & 58,62 & 50,84 & 54,70 & 11,61 & NS \\
\hline $\begin{array}{l}{ }^{1} a, b \mathrm{e} \\
\text { de pas } \\
\text { Prob.: } \\
a, b a \\
\text { of } 0.0 \\
\text { proba } \\
{ }^{2} \text { Linha }\end{array}$ & $\begin{array}{l}\text { parâmetro } \\
0,02,0,05 \text { } \\
\text { statísticas, } \\
\& M c D o n \\
; P d=\text { pot } \\
\text { significant. } \\
\text { rescritas dif } \\
\text { tters differ }\end{array}$ & $\begin{array}{l}\text { s de Ørskov \& } \\
0,08 ; D p=\text { deg } \\
\text { NS: não significa } \\
\text { ald (1979) para } \\
\text { ential degradab }\end{array}$ & $\begin{array}{l}\text { cDonald (1979 } \\
\text { dabilidade pot } \\
\text { vo. } \\
\text { neters; } E d=e \\
\text { lity, } C V \text { : coeff } \\
\text { lo teste Dunca }\end{array}$ & $\begin{array}{l}\mathrm{e}=\mathrm{degr} \\
\text { ial, CV: } \\
\text { ctive deg } \\
\text { nt of var }\end{array}$ & $\begin{array}{l}\text { dade ef } \\
\text { entes d } \\
\text { ility for } \\
(\%), P l\end{array}$ & $\begin{array}{l}\text { ara taxa } \\
\text { ção (\%) } \\
\text { ge rate } \\
\text { atistica }\end{array}$ \\
\hline
\end{tabular}


Esses resultados contrastam com Vagnoni et al. (1995) que observaram diminuição na degradabilidade da FDN da dieta, com o uso de monensina sódica em bovinos, quando realizaram experimento com dieta à base de palha de trigo. Segundo estes pesquisadores, a monensina seria o único fator dietário que realmente afetou a degradabilidade da forragem, diminuindo a degradabilidade potencial da FDN. Essa diminuição na degradabilidade, atribuída a monensina, foi maior em dietas contendo palha de trigo não tratada com amônia, comparado à palha tratada. Os achados do presente estudo contrastam também com Haimoud et al. (1996).

Para o amido dos grãos de milho grão (Tabela 4), a monensina aumentou a degradabilidade efetiva em $9,6 \%, 19,1 \%$ e $24,3 \%$ para taxas de passagens de $2 \%, 5 \%$ e $8 \% / \mathrm{h}$, somente em relação ao grupo tratado com a flavomicina, mas não em relação ao grupo controle. 
Tabela 4 - Degradabilidade ruminal do amido dos grãos de milho obtida com os tratamentos

Table 4 - Ruminal degradability of corn grain starch obtained with treatments

\begin{tabular}{|c|c|c|c|c|c|c|}
\hline & & $\begin{array}{c}\text { Tratamentos } \\
\text { Treatments }\end{array}$ & & & & \\
\hline & $\begin{array}{c}\text { Controle } \\
\text { Control }\end{array}$ & $\begin{array}{c}\text { Flavomicina } \\
\text { Flavomycin }\end{array}$ & $\begin{array}{c}\text { Monensina } \\
\text { Monensin }\end{array}$ & $\begin{array}{c}\text { Média } \\
\text { Mean }\end{array}$ & $\begin{array}{l}\mathrm{CV} \\
\mathrm{CV}\end{array}$ & $\begin{array}{c}\text { Prob. } \\
\text { Prob. }\end{array}$ \\
\hline $\mathrm{a}$ & 3,46 & 4,43 & 5,52 & 4,47 & 47,98 & NS \\
\hline $\begin{array}{l}a \\
\mathrm{~b}\end{array}$ & 99,76 & 100,43 & 96,66 & 98,95 & 2,46 & NS \\
\hline$b$ & & & & & & \\
\hline $\mathrm{c}$ & 0,0549 & 0,0472 & 0,0715 & 0,0578 & 30,36 & NS \\
\hline $\begin{array}{l}c \\
\mathrm{De} 2 \\
E d 2\end{array}$ & $76,07^{\mathrm{ab}}$ & $73,55^{\mathrm{b}}$ & $80,58^{\mathrm{a}}$ & 76,74 & 5,86 & 0,0642 \\
\hline $\begin{array}{l}\text { De5 } \\
\text { Ed5 }\end{array}$ & $55,20^{\mathrm{ab}}$ & $51,99^{\mathrm{b}}$ & $61,90^{\mathrm{a}}$ & 56,36 & 11,19 & 0,0582 \\
\hline $\begin{array}{l}\text { De8 } \\
\text { Ed8 }\end{array}$ & $43,69^{\mathrm{ab}}$ & $40,81^{\mathrm{b}}$ & $50,73^{\mathrm{a}}$ & 45,08 & 13,83 & 0,0499 \\
\hline $\begin{array}{l}\text { Dp } \\
P d\end{array}$ & $103,22^{\mathrm{ab}}$ & $104,86^{\mathrm{a}}$ & $102,18^{\mathrm{b}}$ & 103,42 & 1,77 & NS \\
\hline
\end{tabular}

T $a, b$ e $c$ referem-se aos parâmetros de Ørskov \& McDonald (1979); De = degradabilidade efetiva para taxas de passagem iguais a $0,02,0,05$ e 0,$08 ; \mathrm{Dp}=$ degradabilidade potencial, $\mathrm{CV}$ : coeficientes de variação $(\%)$, Prob.: probabilidades estatísticas, NS: não significativo.

$a, b$ and $c$ are Ørskov \& McDonald (1979) parameters; Ed = effective degradability for passage rates of 0.02, 0.05 and 0.08; $P d=$ potential degradability, $C V$ : coefficient of variation (\%), Prob: statistical probability, NS: non-significant.

${ }^{2}$ Linhas com letras sobrescritas diferentes diferem pelo teste Duncan (5\%).

Rows with different letters differ by Duncan test (5\%).

Aumentos sobre a degradabilidade efetiva do amido poderiam ser considerados benéficos, uma vez que o aumento da taxa de degradação do amido do milho pode resultar em maior disponibilidade de nutrientes no rúmen e, consequentemente, ao animal. Não foram encontrados efeitos da flavomicina sobre os parâmetros de degradação do amido. Degradabilidades potenciais acima de 100\%, como no presente experimento, são comumente encontradas quando se utiliza procedimento estatístico não linear nas curvas de degradação de alguns alimentos. 
Tabela 5 - Degradabilidade ruminal da proteína bruta do farelo de soja obtida com os tratamentos

Table 5 - Ruminal degradability of soybean meal CP obtained with treatments

\begin{tabular}{|c|c|c|c|c|c|c|}
\hline & & $\begin{array}{c}\text { Tratamentos } \\
\text { Treatments }\end{array}$ & & & & \\
\hline & $\begin{array}{c}\text { Controle } \\
\text { Control }\end{array}$ & $\begin{array}{l}\text { Flavomicina } \\
\text { Flavomycin }\end{array}$ & $\begin{array}{l}\text { Monensina } \\
\text { Monensin }\end{array}$ & $\begin{array}{l}\text { Média } \\
\text { Mean }\end{array}$ & $\begin{array}{l}\mathrm{CV} \\
\mathrm{CV}\end{array}$ & $\begin{array}{l}\text { Prob. } \\
\text { Prob. }\end{array}$ \\
\hline$a$ & 14,20 & 12,54 & 16,30 & 14,34 & 17,06 & 0,0798 \\
\hline $\begin{array}{l}a \\
\mathrm{~b} \\
b\end{array}$ & $86,85^{\mathrm{b}}$ & $91,25^{\mathrm{a}}$ & $83,38^{\mathrm{b}}$ & 87,16 & 4,69 & 0,0063 \\
\hline $\mathrm{c}$ & $0,1087^{\mathrm{a}}$ & $0,0750^{\mathrm{b}}$ & $0,1278^{a}$ & 0,1038 & 26,85 & 0,0069 \\
\hline $\begin{array}{l}\text { De2 } \\
E d 2\end{array}$ & 87,45 & 83,45 & 88,33 & 86,41 & 4,02 & NS \\
\hline $\begin{array}{l}\text { De5 } \\
\text { Ed5 }\end{array}$ & $73,55^{\mathrm{ab}}$ & $66,04^{\mathrm{b}}$ & $76,13^{\mathrm{a}}$ & 71,91 & 8,35 & 0,0296 \\
\hline $\begin{array}{l}\text { De8 } \\
\text { Ed8 }\end{array}$ & $64,10^{\mathrm{ab}}$ & $55,63^{b}$ & $67,48^{\mathrm{a}}$ & 62,40 & 10,83 & 0,0296 \\
\hline $\begin{array}{l}\text { Dp } \\
P d\end{array}$ & $101,04^{\mathrm{b}}$ & $103,79^{\mathrm{a}}$ & $99,67^{b}$ & 101,50 & 2,17 & 0,0080 \\
\hline
\end{tabular}

T $a, b$ e $c$ referem-se aos parâmetros de Ørskov \& McDonald (1979); De = degradabilidade efetiva para taxas de passagem iguais a $0,02,0,05$ e 0,$08 ; \mathrm{Dp}=$ degradabilidade potencial, $\mathrm{CV}$ : coeficientes de variação $(\%)$, Prob.: probabilidades estatísticas, NS: não significativo.

$a, b$ and $c$ are Orskov \& McDonald (1979) parameters; Ed = effective degradability for passage rates of 0.02, 0.05 and 0.08; $P d=$ potential degradability, $C V$ : coefficient of variation (\%), Prob: statistical probability, NS: non-significant.

${ }^{2}$ Linhas com letras sobrescritas diferentes diferem pelo teste Duncan (5\%).

Rows with different letters differ by Duncan test (5\%).

Para a PB do farelo de soja (Tabela 5), o tratamento com flavomicina diminuiu a taxa de degradação (parâmetro c) em 31,0\% e 41,3\%, aumentou a fração potencialmente degradável (parâmetro $b$ ) em 5,1\% e 9,4\% e a degradabilidade potencial $(a+b)$ em 2,7\% e 4,1\%, em relação ao grupo controle e ao grupo tratado com monensina, respectivamente. A flavomicina também diminuiu a degradabilidade efetiva da PB do farelo de soja, em relação à monensina, mas não em relação ao controle, quando taxas de passagens de $5 \%$ e $8 \%$ foram utilizadas.

A diminuição da degradabilidade efetiva da PB do farelo de soja causada pela flavomicina, em relação à monensina, variou entre 13,25 e 17,56\% (10,09 e 11,85 
unidades percentuais). Estes efeitos podem ser considerados benéficos em certas condições, uma vez que podem propiciar melhor aproveitamento da proteína dietária pelo animal. Tal resultado é compatível ao experimento realizado por Poppe et al. (1993), onde a suplementação com flavomicina diminuiu a degradabilidade da $\mathrm{MO}$ e da $\mathrm{PB}$ no rúmen e aumentou a quantidade de MO e PB disponível no conteúdo intestinal. A flavomicina parece ter a habilidade de aumentar a quantidade de aminoácidos disponíveis para o animal (EDWARDS et al., 2005), através da diminuição da proteólise ruminal, aumentando a disponibilidade de proteína dietária para absorção intestinal.

Ricke et al. (1984), ao utilizarem a técnica dos sacos de nylon em ovinos alimentados com $67 \%$ de volumoso, não observaram efeito da monensina sobre a taxa de degradação do farelo de soja. Da mesma forma, Rodrigues et al. (2004), ao utilizarem diferentes níveis de monensina e diferentes proporções de volumoso/concentrados na dieta, verificaram que as degradabilidades potenciais $(a+b)$ da MS e PB do farelo de soja aumentaram linearmente com a adição de concentrados, mas nenhum efeito foi observado com adição de monensina.

Em outro experimento realizado por Rodrigues, Lucci e Melotti (2000), foram sugeridas tendências da lasalocida em aumentar a degradação do farelo de soja, quando este alimento permaneceu pouco tempo no rúmen; e de diminuir, quando o tempo de incubação foi prolongado.

Em experimento realizado por Bateman et al. (2004), testando o efeito da monensina sobre a fermentação ruminal, observou-se que a taxa de desaparecimento da PB do farelo de soja dos sacos de nylon (in situ) não foi afetado por este ionóforo. A monensina freqüentemente diminui a degradação protéica no rúmen (BERGEN; BATES, 
1984), porém seu impacto na digestibilidade da MS é variável, dependendo da dieta basal. Se ocorrer aumento na eficiência microbiana devido à adição de monensina, associado ao aumento no fluxo de aminoácidos para o duodeno, pode ocorrer melhora sobre o status protéico do animal (BATEMAN et al., 2004).

Os dados de digestibilidade da matéria seca da dieta e seus nutrientes encontramse na Tabela 6. De forma geral, os dados de digestibilidade das diversas frações, bem como o valor de NDT da dieta, independente do tratamento, encontram-se dentro do esperado. Nenhum dos antibióticos testados alterou a digestibilidade da MS. Resultados semelhantes foram demonstrados por Thornton e Owens (1981) e Zinn, Plascencia e Barajas (1994), onde a monensina não apresentou qualquer efeito sobre a digestibilidade da MS e MO, respectivamente, independente da característica da dieta. 
Tabela 6 - Digestibilidade aparente da MS da dieta e suas frações obtidas com os tratamentos $^{1}$

Table 6 - Apparent digestibility of DM of the diet and its nutrients obtained with treatments

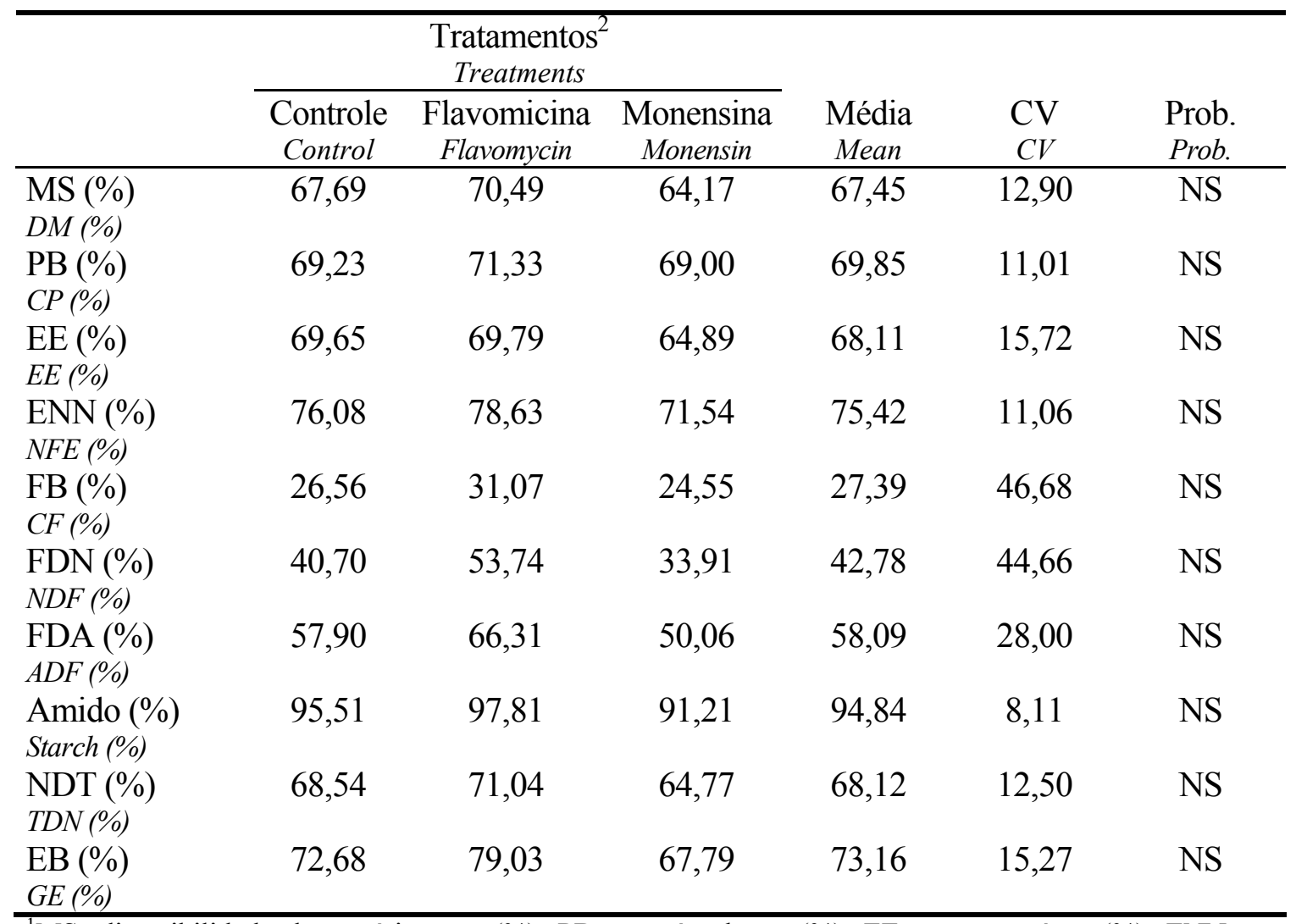

${ }^{1}$ MS: digestibilidade da matéria seca (\%), PB: proteína bruta (\%), EE: extrato etéreo (\%), ENN: extrativos não nitrogenados (\%), FB: fibra bruta (\%), FDN: fibra em detergente neutro (\%), FDA: fibra em detergente ácido (\%), NDT: nutrientes digestíveis totais (\%), EB: energia bruta (\%), CV: coeficientes de variação (\%), Prob.: probabilidades estatísticas, NS: não significativo.

DM: digestibility of dry matter (\%), CP: crude protein (\%), EE: ether extract (\%), NFE: nitrogen-free extract (\%), CF: crude fiber (\%), NDF: neutral detergent fiber (\%), ADF: acid detergent fiber (\%), $T D N$ : total digestible nutrients (\%), GE: gross energy (\%), CV: coefficient of variation (\%), Prob: statistical probability, NS: non-significant.

${ }^{2}$ Linhas com letras sobrescritas diferentes diferem pelo teste Duncan (5\%).

Rows with different letters differ by Duncan test (5\%).

Porém, alguns autores têm demonstrado aumento na digestibilidade da MS e da MO com o uso de ionóforos (DUFF, GALYEAN; BRANINE, 1995; HORTON; BASSENDOWSKI; KEELER, 1980; RICHTER; FLACHOWSKI, 1990; TANNER et al., 1984). Isto está de acordo ao relatado por Pomar et al. (1989), quando demonstraram que a monensina aumentou levemente a digestibilidade da MS somente nas rações ricas 
em volumosos. Já em experimento realizado por McCann et al. (1990), foi demonstrado que este ionóforo apresentou tendência em aumentar a digestibilidade da MO à medida que a proporção de volumosos era diminuída, fato este que foi parcialmente confirmado por Araújo-Febres e Fernández (1991). Alert, Poppe e Lohner (1993) afirmaram também, em experimento com touros confinados, que a suplementação com flavomicina aumentou a digestibilidade aparente da MO, FB e EÑN. Estes dados não estão de acordo com Flachowsky e Richter (1991), os quais, trabalhando com bovinos, relataram que a flavomicina não apresentou influência significativa sobre a digestibilidade aparente da MO ou sobre o NDT, bem como sobre os parâmetros de fermentação ruminal.

Nenhum efeito significativo dos antibióticos sobre a digestibilidade da proteína bruta, extrato etéreo, extrativo não nitrogenado, fibra bruta, amido, energia bruta ou os nutrientes digestíveis totais foi demonstrado. Os antibióticos também não alteraram a digestibilidade da fibra em detergente ácido ou da fibra em detergente neutro.

Os resultados do presente experimento estão de acordo com De Schrijver, Freumat e Claes (1991), que não observaram nenhum efeito significativo da flavomicina sobre a digestão da matéria seca, da fibra bruta ou do extrativo não nitrogenado em carneiros castrados, alimentados com uma mistura de polpa de beterraba com concentrado contendo flavomicina (concentração de 0 ou 10 ppm).

Também são semelhantes aos citados por Zinn, Plascencia e Barajas (1994) e Thornton e Owens (1981), quais não demonstraram qualquer efeito dos ionóforos sobre a digestibilidade da fibra, independente do nível de fibra da dieta. Entretanto, diferem dos resultados observados por Pomar et al. (1989), os quais observaram que a monensina diminuiu a digestibilidade da FDA e FDN em dietas predominantemente concentradas e 
aumentou em dietas predominantemente volumosas. Contrariamente, McCann et al. (1990) e Araújo-Febres e Fernández (1991) demonstraram que a digestibilidade aparente da FDN e da FB aumentou, respectivamente, com o uso de ionóforos, e que este aumento era maior à medida que a proporção de concentrados era aumentada. Poos, Hanson e Klopfenstein (1979), observaram diminuição da digestibilidade da FDA em animais não adaptados à monensina, mas não nos adaptados.

O efeito dos ionóforos sobre a digestibilidade da fibra tem sido comumente explicado na literatura como sendo decorrente do aumento do tempo de retenção da MS no rúmen (ELLIS et al., 1983), decorrente do menor consumo voluntário de alimentos (ROGERS; DAVIS, 1982), melhora das condições ruminais (BRANINE; GALYEAN, 1990) ou aumento do estímulo à ruminação (KNOWLTON; ALLEN; ERICKSON, 1996).

Embora seja aceito que os ionóforos causem pequena a moderada melhora na digestibilidade dos alimentos (SCHELLING, 1984), estas condições não estão definidas até o presente momento, podendo sofrer interferência de fatores como consumo de alimentos, enchimento ruminal, taxa de passagem e outros.

Os dados de consumo de matéria seca digestível e de NDT, expressos em quilos ou em porcentagem do peso vivo dos animais submetidos aos diversos tratamentos, encontram-se na tabela 7. Nenhum dos antibióticos testados alterou estas variáveis. 
Tabela 7 - Consumo de matéria seca digestível e de NDT obtido com os tratamentos ${ }^{1}$ Table 7 - Digestible dry matter and TDN intake obtained with treatments

\begin{tabular}{|c|c|c|c|c|c|c|}
\hline & \multicolumn{3}{|c|}{$\begin{array}{c}\text { Tratamentos }^{2} \\
\text { Treatments }\end{array}$} & \multirow[b]{2}{*}{$\begin{array}{l}\text { Média } \\
\text { Mean }\end{array}$} & \multirow[b]{2}{*}{$\begin{array}{l}\mathrm{CV} \\
\mathrm{CV}\end{array}$} & \multirow[b]{2}{*}{$\begin{array}{l}\text { Prob. } \\
\text { Prob. }\end{array}$} \\
\hline & $\begin{array}{c}\text { Controle } \\
\text { Control }\end{array}$ & $\begin{array}{c}\text { Flavomicina } \\
\text { Flavomycin }\end{array}$ & $\begin{array}{c}\text { Monensina } \\
\text { Monensin }\end{array}$ & & & \\
\hline $\begin{array}{l}\text { CMSD }(\mathrm{kg} / \mathrm{d}) \\
D D M I(\mathrm{~kg} / \mathrm{d})\end{array}$ & 7,08 & 6,27 & 7,10 & 6,81 & 14,41 & NS \\
\hline $\begin{array}{l}\text { CMSD }(\% \mathrm{PV}) \\
D D M I(\% B W)\end{array}$ & 0,921 & 0,875 & 0,951 & 0,916 & 14,15 & NS \\
\hline $\begin{array}{l}\text { CNDT }(\mathrm{kg} / \mathrm{d}) \\
T D N I(\mathrm{~kg} / \mathrm{d})\end{array}$ & 7,17 & 6,32 & 7,17 & 6,88 & 14,08 & NS \\
\hline $\begin{array}{l}\text { CNDT (\%PV) } \\
T D N I(\% B W)\end{array}$ & 0,933 & 0,882 & 0,960 & 0,925 & 13,79 & NS \\
\hline \multicolumn{7}{|c|}{$\begin{array}{l}{ }^{1} \text { CMSD: consumo de matéria seca digestível, CNDT: consumo de nutrientes digestíveis totais, } \\
\text { expressos em } \mathrm{kg} / \text { animal/dia (kg/d) ou porcentagem do peso vivo (\%PV), CV: coeficientes de variação } \\
(\%) \text {, Prob: probabilidades estatísticas, NS: não significativo. } \\
\text { DDMI: digestible dry matter intake, TDNI: total digestible nutrients intake, expressed in } \\
\mathrm{kg} / \text { animal/day (kg/d) or percentage of body weight (\%BW), CV: coefficient of variation (\%), Prob: } \\
\text { statistical probability, NS: non-significant. } \\
\left.{ }^{2} \text { Linhas com letras sobrescritas diferentes diferem pelo teste Duncan ( } 5 \%\right) \text {. } \\
\text { Rows with different letters differ by Duncan test }(5 \%) \text {. }\end{array}$} \\
\hline
\end{tabular}

Estes achados concordam, portanto, com alguns pesquisadores que postularam que não há alteração no consumo de MS com a administração da monensina na dieta (BENZ; JOHNSON, 1982; HAIMOUD et al., 1996; SUBER; BOWMAN, 1998). Também concorda com Rodrigues et al. (2001), que afirmaram não ser possível detectar efeitos da presença de monensina, sobre o consumo de MS, em dietas com diferentes níveis de concentrado. Ainda Zinn, Plascencia e Barajas (1994), Ramanzin et al. (1997) e Rodrigues, Lucci e Castro (2000) afirmaram que a ausência de resposta independe da proporção de concentrados na dieta.

Estes resultados não estão de acordo com Schelling (1984), que afirma ser bem provável que a monensina deprima mais o consumo em dieta concentrada. Mas se a dieta for excessivamente concentrada, e potencialmente acidogênica, é possível que este produto melhore as condições de fermentação ruminal, permitindo manter o 
consumo. Realmente, Osborne et al. (2004), suplementando vacas em lactação durante acidose ruminal, não observaram alteração no consumo de matéria seca.

Ainda segundo Schelling (1984), apesar da monensina deprimir mais o consumo em dieta concentrada (desde que não acidogênica), este produto pode incrementar o consumo em condições de pastejo. Isto está parcialmente de acordo com Arcaro (1998), que afirmou que os ionóforos deprimem mais o consumo em dietas mistas, quando comparadas às predominantemente volumosas. Porém, Baile et al. (1979) afirmaram que os ionóforos reduzem o consumo de alimentos em qualquer que seja a dieta fornecida. 


\section{CONCLUSÃO}

Em condições de dietas predominantemente concentradas, com a cana-de-açúcar como único volumoso, a flavomicina pode melhorar o aproveitamento da PB do farelo de soja, não sendo observado nenhum outro efeito sobre a digestibilidade total dos nutrientes. 


\section{RESUMO}

O presente experimento objetivou estudar os efeitos da administração da flavomicina, em comparação com a monensina sódica, sobre a digestão ruminal (in situ) e total dos nutrientes da dieta em bovinos. Doze fêmeas bovinas não-gestantes e não-lactantes (736 $\mathrm{kg}$ de PV), portadoras de fístula ruminal, foram distribuídas inteiramente ao acaso aos três tratamentos formados por um grupo controle, um grupo tratado com flavomicina e outro tratado com monensina. A flavomicina foi administrada na dose de $20 \mathrm{mg} / \mathrm{animal} / \mathrm{dia}$ e a monensina na dose de 300mg/animal/dia. O experimento teve duração total de 21 dias, sendo os 10 últimos destinados à aplicação do marcador $(15 \mathrm{~g}$ de óxido crômico/animal/dia). Os 5 últimos dias foram destinados à colheita de fezes, amostragem dos alimentos e também à avaliação da digestão ruminal, realizada através da técnica dos sacos de nylon. Os sacos de nylon, contendo milho, farelo de soja ou cana-de-açúcar, foram incubados no rúmen através da fístula ruminal. A monensina aumentou a taxa de degradação do amido do milho grão em 9,6\%, 19,1\% e 24,3\% para as taxas de passagem de 2, 5 e 8\%/h, em relação à flavomicina, mas não em relação ao controle. A flavomicina diminuiu a taxa de degradação da PB do farelo de soja em 31\% em relação ao controle, resultando em diminuição da degradabilidade efetiva para as taxas de passagem de 5 e 8\%/h. Nenhum dos antibióticos testados alterou a degradabilidade efetiva da FDN da cana-de-açúcar ou o consumo de matéria seca digestível ou de NDT. Tão pouco foi alterada a digestibilidade da MS, PB, EE, EÑN, FB, FDA, FDN, amido, EB ou o NDT da dieta. 
Palavras-chave: Consumo. Degradabilidade. Digestibilidade. Ionóforo. Antibiótico nãoionóforo. Ruminantes. 
The objective of this trial was to study the effects of flavomycin administration, compared to sodium monensin, on ruminal degradability and total digestibility in bovine. Twelve non-pregnant and non-lactating cows (736 kg of BW) were randomly assigned to three treatments: control group, flavomycin-treated group and monensin-treated group. Treatments were $20 \mathrm{mg} /$ animal/day of flavomycin or $300 \mathrm{mg} /$ animal/day of monensin. Trial lasted 21 days. The last 10 days were used for external marker administration $(15 \mathrm{~g}$ of chromic oxide/animal/day). The last 5 days of the trial were used for feces collection, feed sampling and evaluation of ruminal degradability using the nylon bag technique. These bags containing corn, soybean meal or sugar cane were incubated through the rumen fistula. Monensin increased the effective degradability of corn grain starch in $9.6 \%, 19.1 \%$ and $24.3 \%$ for passage rates of 2,5 and $8 \% / \mathrm{h}$, compared to flavomycin, but not to control. When compared to control, flavomycin decreased the degradation rate of soybean meal crude protein in $31 \%$, decreasing the effective degradability when passage rates of 5 and $8 \% / \mathrm{h}$ were used. Effective degradability of sugar cane NDF, digestible DMI and TDN were not influenced by the use of either antibiotics; neither were the TND nor the digestibility of DM, CP, EE, NFE, CF, ADF, NDF, GE and starch of the diet.

Key words: Digestion. Degradability. Intake. Ionophore. Non-Ionophore antibiotic. Ruminants. 


\section{REFERÊNCIAS}

A.F.R.C. Technical Committee on Responses to Nutrients. Report No.9. Nutritive requirements of ruminants animals: Protein. Nutrition Abstracts and Reviews, v. 62, n. 12, p. 787-835, 1992.

ALERT, H. J.; POPPE, S.; LOHNER, M. The effect of flavomycin on the fattening performance of bulls. Arch Tierernahr, v. 43, n. 4, p. 371-380, 1993.

AOAC - ASSOCIATION OF OFFICIAL ANALYTICAL CHEMISTS. Official methods of analysis. 10. ed. Washington, D.C.: Association of Analytical Chemistry. 1980. 1015 p.

ARAUJO-FEBRES, O.; FERNÁNDEZ, M. C. Efecto en novillos del monensin y el nivel de fibra de la dieta sobre el consumo y la digestibilidad de la materia seca. Revista de la Facultad de Agronomía, v. 8, n. 2, p .143-153, 1991.

ARCARO, J. R. P. Efeitos da lasalocida sódica sobre o desempenho e composição do leite de vacas Holandesas e Pardo Suíças. 1998. 96p. Dissertação (Mestrado) Faculdade de Medicina Veterinária e Zootecnia, Universidade de São Paulo, Pirassununga, 1998.

BAILE, C. A.; MCLAUGHLIN, C. L.; PATTER, E. L.; CHALUPA, W. Feeding behavior changes of cattle during introduction of monensin with roughage or concentrate diets. Journal of Animal Science, v. 48, n. 6, p. 1501-1508, 1979.

BATEMAN, H. J.; WILLIAMS, C. C.; GANTT, D. T.; CHUNG, Y. H.; BEEM, A. E.; STANLEY, C. C.; GOODIER, G. E.; HOYT, P. G.; WARD, J. D.; BUNTING, L. D. Effects of zinc and sodium monensin on ruminal degradation of lysine-HCL and liquid 2hydroxy-4-methylthiobutanoic acid. Journal of Dairy Science, v. 87, n. 12, p. 25712577, 2004.

BATEMAN, J. Nutrition Animal - Manual de Métodos Analíticos. México: Herrero Hermanos, 1970. p. 405-449.

BENZ, D. A.; JOHNSON, D. A. The effect of monensin on energy partitioning by forage feed steers. Journal of Animal Science, v. 55, p. 491-195, 1982. Suplemento 1.

BERGEN, W. G; BATES, D. B. Ionophores: Their effect on production efficiency and mode of action. Journal of Animal Science, v. 58, n. 6, p. 1465-1483, 1984. 
BRANINE, M. E.; GALYEAN, M. L. Influence of grain and monensin supplementation on ruminal fermentation, intake, digesta kinetics and incidence and severity of frothy bloat in steers grazing winter wheat pasture. Journal of Animal Science, v. 68, n. 3, p. 1139-1150, 1990.

DE SCHRIJVER, R.; FREUMAT, D.; CLAES, B. Flavomycin effects on performance of beef bulls and nutrient digestibility in wethers. Deutsche Tieraerztliche Wochenschrift, v. 98, n. 2, p. 47-50, 1991.

DUFF, G. C.; GALYEAN, M. L.; BRANINE, M. E. Effects of adaptation to lasalocid, monensin or a daily rotation of lasalocid and monensin on in vitro fermentation of a $90 \%$ concentrate diet. Canadian Journal of Animal Science, v. 75, n. 1, p. 129-134, 1995.

EDWARDS, J. E.; MCEWAN, N. R.; MCKAIN, N.; WALKER, N.; WALLACE, R. J. Influence of flavomycin on ruminal fermentation and microbial populations in sheep.

Microbiology, v. 151, n. 3, p. 717-725, 2005.

ELLIS, W. C.; HORN G. W.; DELANEY, D.; POND, K. R. Effects of ionophores on grazed forage utilization and their economic value for cattle on wheat pasture. In: NATIONAL WHEAT PASTURE SYMPOSIUM, 1983, Stillwater. Proceedings of National Wheat Pasture Symposium. Stillwater: Oklahoma Agriculture Experiment Station, [1983]. p. 343. MP - 115

FLACHOWSKY, G.; RICHTER, G. H. Effect of flavomycin on the apparent digestibility of crude nutrients in wethers, parameters of rumen fermentation in cattle and feed intake and weight gain of heifers. Arch Tierernahr, v. 41, n. 3, p. 303-310, 1991.

GRANER, C. A. F. Determinação do crômio pelo método colorimétrico da sdifenilcarbazida. 1972. 112p. Dissertação (Mestrado) - Faculdade de Ciências Médicas e Biológicas, Universidade Estadual Paulista, Botucatu-SP, 1972.

HAIMOUD, A. D.; BAYOURTHE, C.; MONCOULON, R.; VERNAY, M. Avoparcin and monensin effects on digestive function in cows fed a high forage diet. Journal of the Science of Food and Agriculture, v. 70, n. 2, p. 181-189, 1996.

HENDRIX, D. L. Rapid extraction and analysis of nonstructural carbohydrates in plant tissues. Crop Science, v.33, n.6, p.1306-1311, 1993.

HORTON, G. M. J.; BASSENDOWSKI, K. A.; KEELER, E. H. Digestion and metabolism in lambs and steers fed monensin with different levels of barley. Journal of Animal Science, v. 50, n. 6, p. 997-1008, 1980.

KNOWLTON, K .F.; ALLEN, M. S.; ERICKSON, P. S. Lasalocid and particle size of corn for dairy cows in early lactation. 2. Effect on ruminal measurements and feeding behavior. Journal of Dairy Science, v. 79, n. 4, p. 565-574, 1996. 
MAROUNEK, M.; DUŠKOVÁ, D.; SKŘIVANOVÁ, V. Effect of non-ionophore feed antibiotics on in vitro fermentation in the ovine rumen and rabbit caecum. The Journal of Agricultural Science, v. 130, n. 1, p. 115-118, 1998.

MCCANN, M. A.; CRADDOCH, B. F.; PRESTON, R. L.; RANSEY, C B. Digestibility of cotton plant by-products diets for sheep at two levels of intake. Journal of Animal Science, v. 68, n. 2, p. 285-295, 1990.

MEHREZ, A. Z.; ØRSKOV, E. R. A study of the artificial fiber bag technique for determining the digestibility of feeds in the rumen. Journal of Agricultural Science, v. 88, n. 6, p. 645-650, 1977.

NRC - NATIONAL RESEARCH COUNCIL. Nutritional Requirements of Dairy Cattle, 6. ed., Washington D. C.: National Academy Press, 1989.

ØRSKOV, E. R.; MCDONALD, I. The estimation of protein degradability in the rumen from incubation measurements weighted according to rate of passage. Journal of Agricultural Science, v. 92, n. 4, p. 499-503, 1979.

OSBORNE, J. K.; MUTSVANGWA, T.; ALZAHAL, O.; DUFFIELD, T. F.; BAGG, R.; DICK, P.; VESSIE, G.; MCBRIDE, B. W. Effects of monensin on ruminal forage degradability and total tract diet digestibility in lactating dairy cows during grain-induced subacute ruminal acidosis. Journal of Dairy Science, v. 87, n. 6, p. 1840-1847, 2004.

OVCHINNIKOV, Y. A. Physico-chemical basis of ion transport through biological membranes: Ionophores and ion channels. European Journal of Biochemistry, v. 94, p. 321-336, 1979.

PEREIRA, J. R. A.; ROSSI JÚNIOR, P. Manual prático de avaliação nutricional de alimentos. 1. ed. Piracicaba: FEALQ, 1995. 25p.

POMAR, C.; BERNIER, J. F.; SEOANE, F. R.; LATRILLE, L. High-roughage rations with or without monensin for veal production. 2. Ration digestibility. Canadian Journal of Animal Science, v. 69, n. 2, p. 403-410, 1989.

POOS, M. I.; HANSON, T. L.; KLOPFENSTEIN, T. J. Monensin effects on diet digestibility, ruminal protein bypass and microbial protein synthesis. Journal of Animal Science, v. 48, n. 6, p. 1516-1524, 1979.

POPPE, S.; ALERT, H. J.; MEIER, H.; LOHNER, H. The effect of flavomycin on digestion in fattening bulls. Arch Tierernahr, v. 43, n. 4, p. 363-369, 1993.

RAMANZIN, M.; BAILONI, L.; SCHIAVON, S.; BITTANTE, G. Effect of monensin on milk production and efficiency of dairy cows fed two diets differing in forage to concentrate ratios. Journal of Dairy Science, v. 80, n. 6, p. 1136-1142, 1997. 
RICHTER, G. H.; FLACHOWSKI, G. Influence of lasalocid on apparent digestibility, rumen fermentation, fattening and slaughtering performance of bulls. Archives of Animal Nutrition, v. 40, n. 10, p. 981-990, 1990.

RICKE, S. C.; BERGER, L. L.; VAN DER AAR, P. J.; FAHEY, G. C. Effects of lasalocid and monensin on nutrient digestion, metabolism and rumen characteristics of sheep. Journal of Animal Science, v. 58, n. 1, p. 194-202, 1984.

RODRIGUES, P. H. M.; LUCCI, C. S.; CASTRO, A. L. Efeitos da lasalocida sódica e proporção volumoso/concentrados sobre a fermentação ruminal em vacas secas.

Brazilian Journal of Veterinary Research and Animal Science, v. 37, n. 3, p. 253 258, 2000.

RODRIGUES, P. H. M.; LUCCI, C. S.; MELOTTI, L. Efeitos da lasalocida sódica e proporção volumoso/concentrados sobre a degradabilidade in situ do farelo de soja e do feno coast cross [Cynodon dactylon (L.) Pers.] em vacas secas. Brazilian Journal of Veterinary Research and Animal Science, v. 37, n. 3, p. 259-264, 2000 .

RODRIGUES, P. H. M.; MATTOS, W. R. S.; MELOTTI, L.; RODRIGUES, R. R. Monensina e digestibilidade aparente em ovinos alimentados com proporções de volumoso/concentrado. Scientia Agricola, v. 58, n. 3, p. 449-455, 2001.

RODRIGUES, P. H. M.; MATTOS, W. R. S.; MEYER, P. M.; LUCCI, C. S.; MELOTTI, L. Effects of monensin level and roughage/concentrate ratio on ruminal fermentation in bovines. Journal of Animal and Feed Science, v. 13, p. 195-198, 2004. Suplemento 1.

ROGERS, J. A.; DAVIS, C. L. Rumen volatile fatty acid production and nutrient utilization in steers fed a diet supplemented with sodium bicarbonate and monensin. Journal of Dairy Science, v. 65, n. 6, p. 944-952, 1982.

SAS - STATISTICAL ANALISYS SYSTEM. SAS user's guide: Statistics. Versão 5. Cary: SAS, 1985.

SCHELLING, G. T. Monensin mode of action in the rumen. Journal of Animal Science, v. 58, n. 6, p. 1518-1527, 1984.

SUBER, L. M.; BOWMAN, J. G. Monensin effects on digestion of corn or barley high-concentrate diets. Journal of Animal Science, v. 76, n. 7, p. 1945-1954, 1998.

TANNER, J. W.; BYERS, F. M.; ELLIS, W. C.; SCHELLING, G. T.; GREENE, L. W. Effect of two ionophores on digestibility, gastrointestinal fill and utilization of winter pasture by grazing heifers. Journal of Animal Science, v. 59, p. 67, 1984. Suplemento 1. 
THORNTON, J. H.; OWENS, F. N. Monensin supplementation and in vivo methane production by steers. Journal of Animal Science, v. 52, n. 3, p. 628-634, 1981.

VAN SOEST, P. J.; ROBERTSON, J. B.; LEWIS, B. A. Methods for dietary fiber, neutral detergent fiber, and nonstarch polysaccharides in relation to animal nutrition. Journal of Dairy Science, v. 74, n. 10, p. 3583-3597, 1991.

VAGNONI, D. B.; CRAIG, W. M.; GATES, R. N.; WYATT, W. E.; SOUTHERN, L. L. Monensin and ammoniation or urea supplementation of bermudagrass hay diets for steers. Journal of Animal Science, v. 73, n. 6, p. 1793-1802, 1995.

ZINN, R. A; PLASCENCIA, A.; BARAJAS, R. Interaction of forage level and monensin in diets for feedlot cattle on growth performance and digestive function. Journal of Animal Science, v. 72, n. 9, p. 2209-2215, 1994. 


\section{CAPÍTULO V}

\section{CONSIDERAÇÕES FINAIS}

A monensina é um antibiótico ionóforo classicamente conhecido por alterar os parâmetros fermentativos ruminais, como aumentar a proporção molar de ácido propiônico, diminuir a proporção molar de ácido acético, sem alterar consideravelmente a concentração total de AGVs, fato este confirmado neste experimento.

Já o antibiótico não-ionóforo flavomicina é conhecido por seu menor potencial em alterar a porcentagem molar dos AGVs, fato este também confirmado no presente estudo. Diferente da monensina, a flavomicina não aumenta a proporção molar de ácido propiônico, porém possui a capacidade de diminuir a proteólise ruminal, pois atua sobre as bactérias AAPA (alta atividade de produção de amônia). Embora não fosse demonstrado diminuição na concentração ruminal de amônia, foi demonstrado diminuição na taxa de degradação da PB do farelo de soja, o que também está de acordo com a literatura.

Pode-se considerar, portanto, que a monensina melhora o metabolismo energético e protéico, enquanto que a flavomicina melhora essencialmente o metabolismo protéico do animal. 